\title{
Experimental Study on the Corrosion of Carbon Steel and Aluminum Alloy in Firefighting Protein Foam Concentrates
}

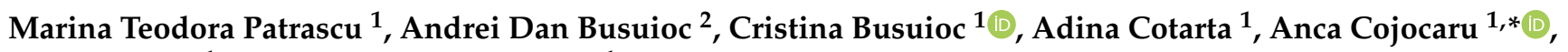 \\ Teodor Visan ${ }^{1}$ and Danut Ionel Vaireanu ${ }^{1}$ \\ 1 Faculty of Applied Chemistry and Materials Science, University Politehnica of Bucharest, \\ 060042 Bucharest, Romania; marina.patrascu@ymail.com (M.T.P.); jinga_cristina@yahoo.co.uk (C.B.); \\ adina@cael.pub.ro (A.C.); t_visan@chim.upb.ro (T.V.); di_vaireanu@yahoo.co.uk (D.I.V.) \\ 2 General Inspectorate for Emergency Situations (IGSU), 023765 Bucharest, Romania; busu1569@gmail.com \\ * Correspondence: anca.cojocaru@chimie.upb.ro
}

check for

updates

Citation: Patrascu, M.T.;

Busuioc, A.D.; Busuioc, C.;

Cotarta, A.; Cojocaru, A.; Visan, T.;

Vaireanu, D.I. Experimental Study on the Corrosion of Carbon Steel and Aluminum Alloy in Firefighting Protein Foam Concentrates. Materials 2021, 14, 7259. https://doi.org/ $10.3390 /$ ma14237259

Academic Editor: Sergey E. Barykin

Received: 3 November 2021

Accepted: 22 November 2021

Published: 27 November 2021

Publisher's Note: MDPI stays neutral with regard to jurisdictional claims in published maps and institutional affiliations.

Copyright: (c) 2021 by the authors. Licensee MDPI, Basel, Switzerland. This article is an open access article distributed under the terms and conditions of the Creative Commons Attribution (CC BY) license (https:/ / creativecommons.org/licenses/by/ $4.0 /)$.

\begin{abstract}
The corrosion of mild steel and $\mathrm{Al}$ alloy in Fomtec P 6\% and 6\% P Profoam 806 proteinbased foam concentrates was investigated. Weight-loss data for steel showed corrosion penetration of 0.745 mipy in Fomtec and 2.269 mipy in Profoam, whereas for Al alloy the penetration levels were 0.474 and 1.093 mipy, respectively. Scanning electron microscopy and energy dispersive X-ray spectroscopy allowed characterization of the metallic surface covered or free from corrosion products. Values of corrosion potential, corrosion current density and corrosion penetration were calculated by using potentiodynamic polarization curves. Electrochemical impedance spectra illustrated the change in polarization resistance during anodic polarization. Data obtained by accelerated electrochemical methods confirm the greater aggressiveness of the Profoam concentrate compared to Fomtec concentrate.
\end{abstract}

Keywords: corrosion of fire fighting equipment; protein foam concentrate; carbon steel; $\mathrm{AlSiCuMg}$ aluminum alloy; methods for corrosion rate determination

\section{Introduction}

Corrosion of metallic materials is one of the most significant issues for all industrial sectors, among which are sewage pipelines and firefighting service, involved in terms of both lifecycle cost and system reliability [1]. It has been shown that corrosion problems, when working with protein-based agents, can occur on a wide range of complex devices, especially for storage and proportionating systems.

Corrosion processes occur in foam storage tanks, piping, in-line inductors (eductors) such as Venturi tubes, hose couplings and nozzles-all being exposed to firefighting agents used as either liquid concentrates or as already prepared foam [2-5]. Corrosion is known to produce many problems in fire protection systems, especially wet and preaction fire sprinklers [6-14]. Carpen et al. [15,16] analyzed the failure of stainless steel pipes in fire protection systems of a hot rolling mill and of a power plant, in contact to natural or tap water containing chloride, manganese and iron ions. Su and coworkers [4,17-20] showed that corrosion products such as tubercles and scale are deposited on galvanized and carbon steel, impairing the effectiveness of sprinkler systems.

The last two decades have seen a number of advances in the quality of firefighting foams [21-26] capable of rapidly suppressing and extinguishing the class B pool fires. Aqueous film forming foams (AFFFs) have gained much attention because they are the most effective fire extinguishing agents for fighting hydrocarbon liquid fuel fires and chemical solvent fires. Today, all available AFFF concentrates have in their chemical compositions a fluorocarbon surfactant (as a key component), a hydrocarbon surfactant and an organic solvent [27]. In practice, the foam is routinely prepared by diluting the commercial 1-6\% extinguishing concentrate with water and forcing the gas (air, nitrogen) 
into this solution. Unfortunately, it was noticed that the fluorinated (or polyfluorinated) surfactants possess complex environmentally harmful behavior because they are persistent, potentially bio-accumulative and toxic.

In order to decrease the toxicity and cost, regular protein-based and fluoroprotein foams were widely introduced in practice and are expected to have good biodegradability [28-30]. The protein-based concentrates are fabricated from hydrolyzed protein obtained from either animal keratin or a vegetable source; a suitable solvent; a stabilizer; and a preservative. The added fluorinated surfactant makes them more effective. Concentrates for film forming fluoroprotein foam and corresponding alcohol resistant aqueous film-forming foam are more interesting due to their better firefighting performance, better burn-back resistance and lack of degradation over time.

However, the use of conventional aqueous film-forming foam is now severely restricted, and AFFFs must be replaced without sacrificing fire suppression performances. Notably, a group from the US Naval Research Laboratory [31-36] has recently showed that a difficulty with replacing fluorocarbon surfactants in AFFFs is due to the complexity of commercial formulations; another problem is that the effects of individual component on foam properties are not well understood. An ecological alternative would be the use of synthetic concentrates for fluorine-free foams [37-40], but it seems that these proposed solutions cannot yet extinguish as efficiently as AFFFs [31,41]. Protein-based formulations were identified as alternative solutions/replacements. Currently, protein-base foams are marketed by Profoam Corporation, Rutledge, Georgia, US (Provex AR 6-6), Angus Chemical Company, Buffalo Grove, Illinois, US (perfluoroalkyl substance-based foams TF3 and TF90) and Dr. Sthamer company GhmbH \& Co., Hamburg, Germany (Foamousse). In general, fluorine-free foams exhibit much better foam stability but worse foam spread property than commercial AFFF. Only a fluorine-free foam containing a silicone surfactant showed better fire extinguishing and burn-back performance [40].

In firefighting systems, the walls of large storage vessels, commonly made of low carbon steel (cold-rolled), get corroded due to the foam concentrate that may drill the metal. Corrosion has caused problems over the years, and alternative materials had to be considered. Repair welding is expensive, and other options are used; for instance, storage tanks could be fabricated of carbon steel covered with baked phenolic lining and certain room temperature-cured coatings [42]. Carbon steels A53-A106 are not recommended for storage of protein-based AFFFs due to the corrosiveness of protein foam agents [43]. To overcome these issues, carbon steel was gradually replaced, and 304 or 316 austenitic stainless steel started to be used. Additionally, the foam concentrate piping was recommended to be made of stainless steel and brass, whereas cast iron and bronze remained the materials for the construction of pumps and valves.

The nozzles made from aluminum alloys are damaged by the corrosive attack of the foam during repeated usage. In Romania, firefighters are using Storz type couplings (hose couplings, adapters and blank caps) fabricated of die cast aluminum alloy. Unfortunately, the most used metallic materials in their fire service's technical arsenal tend to be more susceptible to localized corrosion, which is often difficult to detect and to monitor effectively. Moreover, $\mathrm{Al}$ alloys may take up hydrogen during their processing and use, and the absorbed hydrogen is transported into the alloy and may be trapped at different preferred sites. Some researchers have reported, very recently, that during the formation of the protective oxide layer on the surface of commercial aluminum alloys, the crack growth is enhanced $[44,45]$ due to absorption of reactive atomic hydrogen produced by the humidity from the environment. The electrochemical process is: $\mathrm{H}_{2} \mathrm{O}+\mathrm{e}^{-} \rightarrow \mathrm{OH}^{-}+\mathrm{H}_{\mathrm{abs}}$. One consequence is that crack propagation around second-phase particles or grain boundaries can be ten times worse in humid air than in a vacuum, leading to hydrogen embrittlement susceptibility of the aluminum alloys. Thus, the question of corrosion of metallic construction materials due to fire extinguishing agents has become an issue of concern, and one of the most difficult problems in the fire service. 
In fire engineering, the corrosion of carbon steel and aluminum alloys in contact with firefighting foams used to effectively extinguish fires has not yet extensively been studied. One of the first studies in the United States of the corrosion characteristics of a protein-type foam was conducted on cold-rolled carbon steel, 304 stainless steel and 1100 and 5052 aluminum alloys [46]. Stainless steel has shown an excellent corrosion resistance compared to carbon steel. The research involving the aggressiveness of a protein-based agent in comparison with an AFFF (FC-195 light water) has been continued with the abovementioned steels and other common metals and alloys $(\mathrm{Cu}, \mathrm{Pb}, \mathrm{Zn}, \mathrm{Ti}$, brass, Monel and CuNi alloy) [2]. The corrosivity of the standard protein concentrate toward carbon steel has been found to be about 13 times higher than of light water, whereas stainless steel had a corrosion rate of zero. The corrosion properties of seven foam firefighting agents (among them were 3M FC 203 CE, Angus FP 70 and National Foam XL3, all with 21-38 g/L $\mathrm{Cl}^{-}$content) were examined by Scheffey and Wright [3]. By testing common construction materials, carbon steel (UNS G10100), 304 stainless steel and 6061 aluminum alloy, the authors found that the corrosion rate was not proportional to the halide content of the extinguishing agent. Angus FP 70 was found to be the most corrosive for carbon steel. A study of metal compatibility with fluoroprotein surfactant and fluoropolymer-free foam concentrates (RF Solberg as 3\%, $6 \%$ and $3 \times 6$ ATC formulations) was also performed [41]. Immersion testing was done for pure metals $(\mathrm{Al}, \mathrm{Cu})$, cast iron, mild and stainless steels and alloys (brass, bronze, $\mathrm{CuNi}$, Monel, alloys of $\mathrm{Mg}$ or Ti). The weight losses in the coupons determined in comparison with values in distilled water showed that water is more aggressive than concentrates or their diluted solutions.

Few corrosion studies involving a firefighting service have been performed outside the United States. Papers published by Radwan et al. and Rakowska et al. $[5,47,48]$ described uniform and localized corrosion of fire extinguishing equipment, suggesting the most important methods of corrosion prevention or mitigation. Kostyaev et al. [49] have investigated the corrosiveness of PO-6TS-M concentrate (AFFF from IvKhimProm AO, Ivanovo, Russia), which comprises the PO-6TS fluorochemical surfactant and ethylene glycol. The corrosion behavior of St3 carbon steel in a premixed aqueous solution (concentrate diluted in a 1:17 ratio) was evidenced by measuring weight loss and by potentiodynamic polarization. The introduction of more than $0.5 \mathrm{~g} / \mathrm{L}$ additives from antipyrene class ensured complete steel passivation. Elahresh and Jewilli [50] evidenced the corrosion on 304 stainless steel in 3\% Hydral foam concentrate (from Sabo Foam SRL, Bergamo, Italy), which is a highly efficient type of synthetic AFFF fire suppressant agent. Experiments showed close agreement between weight loss data and electrochemical measurement (anodic polarization).

The main purpose of the present research was to study the corrosion of carbon steel and an aluminum alloy, which are commonly used as construction metallic materials in firefighting, in Fomtec P 6\% and 6\% P Profoam 806 aggressive foam concentrates. To the best of our knowledge, this is the first study about the corrosivity of these commercial protein-based foam concentrates.

\section{Materials and Methods}

The investigated metal corrosion behavior refers to equipment in fire extinguishing vehicles, e.g., Iveco, Volvo, Dac-Lancer, APCA (including APCA-T and APCAA R 12215 DFA) trucks used by Romanian firefighters. Steel samples were taken from $4 \mathrm{~mm}$ thick walls of the containers and pipes made from cold-rolled low carbon steel. This low cost mild steel is named in Romania as OL $42.2 \mathrm{k}$ steel (SR EN 10025-A1/1994) and is similar to S275 JR steel (EN 10025-2/2004), RSt 42.2 steel (DIN 17100), Fe 430B steel (ISO 630), or 50 grade steel (ASTM A529). It has nominal composition (wt\%): $0.6 \mathrm{Mn} ; 0.33 \mathrm{C} ; 0.045 \mathrm{P}$; $0.045 \mathrm{~S}$; Fe-balance. Selected Storz hose couplings samples were made from cast aluminum alloy with a composition closer to AlSi5Cu1Mg alloy (EN AC-45300), with a content (wt\%) in limits of: $86-93 \mathrm{Al} ; 5-13 \mathrm{Si} ; 1.0-1.5 \mathrm{Cu} ; 0.6-0.75 \mathrm{Mg}$; $0.2 \mathrm{Fe} ; 0.2 \mathrm{Ti} ; 0.2 \mathrm{Ni} ; 0.1 \mathrm{Mn} ; 0.1 \mathrm{Zn}$. 
The investigated fluorine free foam concentrates considered as the aggressive media were Fomtec P 6\% (Dafo Fomtec AB, Stockholm, Sweden) and 6\% P Profoam 806 (Profoam, Profoam International, Paris, France) commonly used by Romanian firefighters. Due to its proprietary nature, the chemical composition of foam concentrates is not generally published by the manufacturers. We only know that both protein foam concentrates are produced by a controlled blend of hydrolyzed animal proteins (70-0 wt \%), hexylene glycol $(<6 \mathrm{wt} \%)$, diclorometaxylenol ( $<0.5 \mathrm{wt} \%$ as bactericide), and foam boosters, antifreeze agents, stabilizers and preservatives. The concentrates also contain $8-15 \mathrm{wt} \%$ metal salts as chlorides (sodium, manganese) and $<0.2 \mathrm{wt} \%$ sulphates (iron). The $\mathrm{pH}$ of concentrates, measured by us, was in the range of 9 to 10, which is slightly more alkaline than the values given by the manufacturer ( $\mathrm{pH} 6-8$ ). Both dark brownish liquids are non-toxic and biodegradable and should be diluted with fresh or sea water at a 6-part concentrate to 94-part water ratio.

For weight-loss determination the steel specimens were cut into rectangular strips with $25-28 \mathrm{~cm}^{2}$ surface area. Large curved or even profiled coupons of $\mathrm{Al}$ alloy having 15-17 $\mathrm{cm}^{2}$ surface area were cut from Storz hose couplings. The surface was finished by polishing it successively with $\mathrm{SiC}$ emery paper up to 2500 grit, then rinsed successively with tap water, deionized water, cleaned with acetone, dried with flowing air and finally weighed.

The measurements were conducted at ambient temperature $\left(22 \pm 2{ }^{\circ} \mathrm{C}\right)$ under vertical immersion of prepared metal specimens into beakers filled with equal volumes of $150 \mathrm{~mL}$ foam concentrate (aerated and refreshed periodically). At the end of gravimetric test some coupons were gentle scrubbed, rinsed with deionised water, allowed to dry in laboratory air and analyzed by microscopy. The corrosion products were removed from surface by brushing, intense rinsing with deionized water, drying and then each coupon was re-weighed accurately. Weight loss was determined with an analytical balance with a precision of $0.1 \mathrm{mg}$ at different time intervals, the longest exposure period being 348 days for steel and 14 days for $\mathrm{Al}$ alloy.

The surface morphology of the exposed samples with and without corrosion products was observed by scanning electron microscopy (SEM) using FEI Quanta Inspect F (Philips, Eindhoven, Netherlands) microscope equipped with energy dispersive X-rays (EDS) device ((FEI Company, Hillsboro, OR, USA).) for elemental microanalysis. Both Everhart-Thornley secondary electron detector (ETD) (FEI Company, Hillsboro, OR, USA). and circular backscatter detector (CBS) (FEI Company, Hillsboro, OR, USA). were used for obtaining SEM images.

Laboratory-accelerated corrosion experiments as electrochemical testing were performed using a SP-150 BioLogic Sci. Instr. Potentiostat (BioLogic, Seyssinet-Pariset, France). All sample materials and foam concentrates used in these tests were identical to those used in the weight loss measurements. In the electrochemical cell the working electrode had a $1 \mathrm{~cm}^{2}$ exposed surface area of either $42.2 \mathrm{k}$ steel or cast $\mathrm{Al}$ alloy by embedding in epoxy resin/polytetrafluoroethylene composite. A platinum plate $\left(10 \mathrm{~cm}^{2}\right)$ and $\mathrm{Ag} / \mathrm{AgCl} / 3 \mathrm{M}$ $\mathrm{KCl}$ electrode ( Metrohm AG, Herisau, Switzerland were the auxiliary electrode and reference electrode, respectively. Semi-logarithmic potentiodynamic polarization curves were recorded with $3 \mathrm{mV} / \mathrm{s}$ sweep rate around the open-circuit potential to study the corrosion behavior of metallic samples. The specimens were immersed $30 \mathrm{~min}$ in the foam concentrate prior to the measurement in order to stabilize the open-circuit potential. Values of corrosion potential and corrosion current density were calculated at the intercept of the anodic and cathodic Tafel lines. The polarization resistance (a parameter which is inversely proportional to corrosion current) was determined experimentally by using electrochemical impedance spectroscopy (EIS). EIS spectra as Nyquist and Bode diagrams were obtained by using a superimposed $10 \mathrm{mV}$ peak-to-peak ac voltage perturbation for the scanning frequency range from $100 \mathrm{kHz}$ to $50 \mathrm{mHz}$ and by polarizing the sample surface at various electrode potentials. The impedance data were further processed using an impedance module (FRA) of potentiostat and were modeled with ZView 2.4 software from Scribner Association Inc., Southern Pines, NC, USA. All electrochemical tests were conducted in 
freshly foam liquid concentrates at $22 \pm 2{ }^{\circ} \mathrm{C}$, and the results were repeated to check the reproducibility.

\section{Results and Discussion}

Being derived from natural products, the used protein-based foam concentrates are very quickly biodegradable compared to alternatives, and they do not require the use of environmentally harmful glycol additives, which are necessary in synthetic-based foams, especially for low-temperature use. It would be unsurprising for these organic substances not to lead to intense corrosion. However, as we mentioned above, the investigated protein foam concentrates contain inorganic salts (chloride, sulphate), which can be more aggressive. This contribution describes the experimental program undertaken to test the corrosivity of Fomtec P $6 \%$ and $6 \%$ P Profoam 806 firefighting foam concentrates in storage steel vessels or flowing into piping and Storz couplings made of $\mathrm{Al}$ alloy (with composition closer to AlSi5Cu1Mg alloy) for fire hoses. Their effects on the corrosion of carbon steel and $\mathrm{Al}$ alloy have not been systematically reported until now.

\subsection{Long Exposure Study by Weight Losses}

The gravimetric method of weight loss determination is the most widely used method of corrosion assessment due to its simplicity and reliability. The long exposure time of coupons immersed in liquid foam concentrates is important, since quick tests of accelerated corrosion give results which can sometimes be misleading. Unfortunately, the extremely dark color and opacity of the concentrates precluded the visual observation of the presence of metal ions in solution, and also of other accompanying insoluble corrosion products. Experimentally determined weight loss was converted to either gravimetric corrosion index $(\mathrm{kg})$, or expressed as milligrams per square decimeter per day (mdd) or penetration rate $C R$ (milli-inch per year, mipy), meaning the average depth of metal loss. We considered $8760 \mathrm{~h}$ to constitute a year.

\subsubsection{Corrosion of Carbon Steel}

Table 1 displays the determined corrosion parameters for $42.2 \mathrm{k}$ steel after different exposure time periods of up to 348 days. In calculations of corrosion penetration, a $7.86 \mathrm{~g} / \mathrm{cm}^{3}$ density value of $42.2 \mathrm{k}$ steel was taken. Corrosion attack levels were measured as integral weight losses, but the data allowed us to calculate them incrementally too. We supposed a uniform penetration rate, which is an engineering guide for designing the life expectancy of wall for tanks or pipes. The data obtained were fairly reproducible.

The gravimetric experiments showed that corrosion rate of steel in Fomtec P 6\% increased continuously over time. Steel samples in Profoam concentrate were much more corroded over the entire exposure period. However, the largest value of corrosion rate was after the first 81 days of immersion. Then it was clearly attenuated, suggesting a steadystate corrosive attack within the period of 81-232 days (see differential values denoted by *). It seems that a stationary state was kept for longer periods of time in both corrosive media. As we discuss below for SEM images, this can be explained by the behavior of the layers formed by continuous corrosion (uniform corrosion) of the Fe component of steel. The corrosion products formed by interaction with protein and $\mathrm{Cl}^{-}$(and $\mathrm{SO}_{4}{ }^{2-}$ ) from the foam solution can remain as a porous layer or detach from the metal surface and dissolve via diffusion into the bulk solution, so this layer does not protect the rest.

Our data are in good agreement with values of corrosion rate determined previously. Bertschy et al. [2] reported that the storage of light water concentrate in a carbon steel vessel produced a corrosion rate of $18.2 \mathrm{mdd}$. Values of penetration rate of 0.6-1.4 mipy for rolled low carbon steel (UNS G 101100) in protein foam concentrate were determined by Scheffey and Wright [3], who mentioned that the 1.6 mipy value is the maximum permissible corrosion rate in the US for this steel in a foam, under MIL-F-24385C. Our results obtained for steel corrosion in Fomtec fall within this allowed limit, whereas values for Profoam slightly exceed this limit. However, our data are significantly lower than the 
values for cold-rolled carbon steel of $18.2 \mathrm{mdd}$ determined in a light water concentrate and of $134 \mathrm{mdd}$ in a very corrosive protein foam concentrate [46].

Table 1. Corrosion rates expressed as gravimetric index $(\mathrm{kg})$ and penetration rate for $42.2 \mathrm{k}$ steel in the two foam concentrates.

\begin{tabular}{|c|c|c|c|c|c|}
\hline \multirow{2}{*}{$\begin{array}{c}\text { Steel } \\
\text { Sample }\end{array}$} & \multicolumn{5}{|c|}{$\begin{array}{c}k g(\mathrm{mdd}) \text { after Different Immersion Periods of Time. in Brackets: } \\
\text { Penetration Rate (mipy) }\end{array}$} \\
\hline & 29 Days & 63 Days & 81 Days & 232 Days & 348 Days \\
\hline \multicolumn{6}{|c|}{ Fomtec P 6\% concentrate } \\
\hline 1 & $\begin{array}{c}2.551 \\
(0.466)\end{array}$ & $\begin{array}{c}3.233 \\
(0.591)\end{array}$ & $\begin{array}{c}3.278 \\
(0.599)\end{array}$ & $\begin{array}{c}2.990 \\
(0.547)\end{array}$ & $\begin{array}{c}2.962 \\
(0.543)\end{array}$ \\
\hline 2 & $\begin{array}{c}2.654 \\
(0.484)\end{array}$ & $\begin{array}{c}3.190 \\
(0.583)\end{array}$ & $\begin{array}{l}3.204 \\
(0.587)\end{array}$ & $\begin{array}{l}3.396 \\
(0.622)\end{array}$ & $\begin{array}{c}3.672 \\
(0.673)\end{array}$ \\
\hline 3 & $\begin{array}{c}3.552 \\
(0.650)\end{array}$ & $\begin{array}{c}4.258 \\
(0.779)\end{array}$ & $\begin{array}{c}4.236 \\
(0.776)\end{array}$ & $\begin{array}{l}5.568 \\
(1.016)\end{array}$ & $\begin{array}{c}5.594 \\
(1.020)\end{array}$ \\
\hline Average & $\begin{array}{c}2.919 \pm 0.550 \\
(0.533 \pm 0.060)\end{array}$ & $\begin{array}{c}3.560 \pm 0.604 \\
(0.651 \pm 0.111)\end{array}$ & $\begin{array}{c}3.573 \pm 0.576 \\
(0.654 \pm 0.106)\end{array}$ & $\begin{array}{c}3.985 \pm 1.386 \\
(0.728 \pm 0.252) \\
\end{array}$ & $\begin{array}{c}4.076 \pm 1.362 \\
(0.745 \pm 0.247)\end{array}$ \\
\hline \multicolumn{6}{|c|}{ 6\% P Profoam 806 concentrate } \\
\hline 4 & $\begin{array}{c}7.174 \\
(1.311) \\
\end{array}$ & $\begin{array}{c}9.602 \\
(1.756)\end{array}$ & $\begin{array}{l}11.424 \\
(2.087) \\
\end{array}$ & $\begin{array}{c}8.693 \text { and } 7.226^{*} \\
\left(1.589 \text { and } 1.311^{*}\right)\end{array}$ & $\begin{array}{l}10.205 \\
(1.866)\end{array}$ \\
\hline 5 & $\begin{array}{c}8.798 \\
(1.610) \\
\end{array}$ & $\begin{array}{l}13.994 \\
(2.559)\end{array}$ & $\begin{array}{l}14.304 \\
(2.614)\end{array}$ & $\begin{array}{l}11.194 \text { and } 9.523 * \\
(2.047 \text { and } 1.740 *)\end{array}$ & $\begin{array}{l}12.180 \\
(2.228)\end{array}$ \\
\hline 6 & $\begin{array}{c}7.411 \\
(1.354) \\
\end{array}$ & $\begin{array}{c}9.890 \\
(1.807)\end{array}$ & $\begin{array}{l}11.513 \\
(2.106)\end{array}$ & $\begin{array}{c}9.103 \text { and } 7.810^{*} \\
\left(1.665 \text { and } 1.429^{*}\right)\end{array}$ & $\begin{array}{l}10.586 \\
(1.937)\end{array}$ \\
\hline Average & $\begin{array}{c}7.794 \pm 0.877 \\
(1.425 \pm 0.162)\end{array}$ & $\begin{array}{l}11.162 \pm 2.457 \\
(2.041 \pm 0.446)\end{array}$ & $\begin{array}{l}12.414 \pm 1.482 \\
(2.269 \pm 0.299)\end{array}$ & $\begin{array}{c}9.663 \pm 1.341 \\
(1.767 \pm 0.245)\end{array}$ & $\begin{array}{l}10.990 \pm 1.012 \\
(2.010 \pm 0.192)\end{array}$ \\
\hline
\end{tabular}

* These additional results are differential corrosion rates calculated from experimental data within the period of 81-232 days.

Prior corrosion experiments, SEM images and EDS elemental analysis of $42.2 \mathrm{k}$ steel showed that it has a surface morphology and a chemical composition with good homogeneity and uniform distribution of iron, manganese and other constituents. Following exposure to foam concentrate, the steel samples were observed to have undergone visible degradation. In general, as the exposure time was prolonged, the color of sample became darker. Additionally, we noticed during weight-loss experiments a change in color in some surface locations from yellow-brown (phase assigned to $\beta-\mathrm{FeOOH}$ ) to green blue-greyish (phase assigned to the oxides/hydroxides mixture of Fe(II)/Fe(III) as a stable film). Due to the expansive nature of the corrosion products, it is possible to develop mechanical stress in the corrosion layer, thereby inducing two opposing effects-namely, pore blocking and the formation of cracks. Besides uniform corrosion, the SEM images of steel samples showed pitting corrosion.

Figures 1 and 2 illustrate the morphologies of the corroded $42.2 \mathrm{k}$ steel samples with and without corrosion products after the 166 days of immersion in Fomtec P 6\%. Figure 1 shows SEM micrographs (ETD and CBS images) of surfaces covered with the corrosion products together with the EDS spectrum of the corrosion products. SEM images indicate that the steel immersed in Fomtec over a long period of time was covered with a noncompact film having numerous breaks, which represent sites for the continuous penetration of the aggressive liquid towards the metallic substrate, the process responsible for severe corrosion over time. Figure 2 shows, for two corroded samples, a non-regular surface visible after the corrosion products' removal, suggesting the destructive attack occurred in the carbon steel bulk. At every magnification, the cracks, grooves and circular caverns in the sample mass were detected, all of which were the results of localized corrosion. 

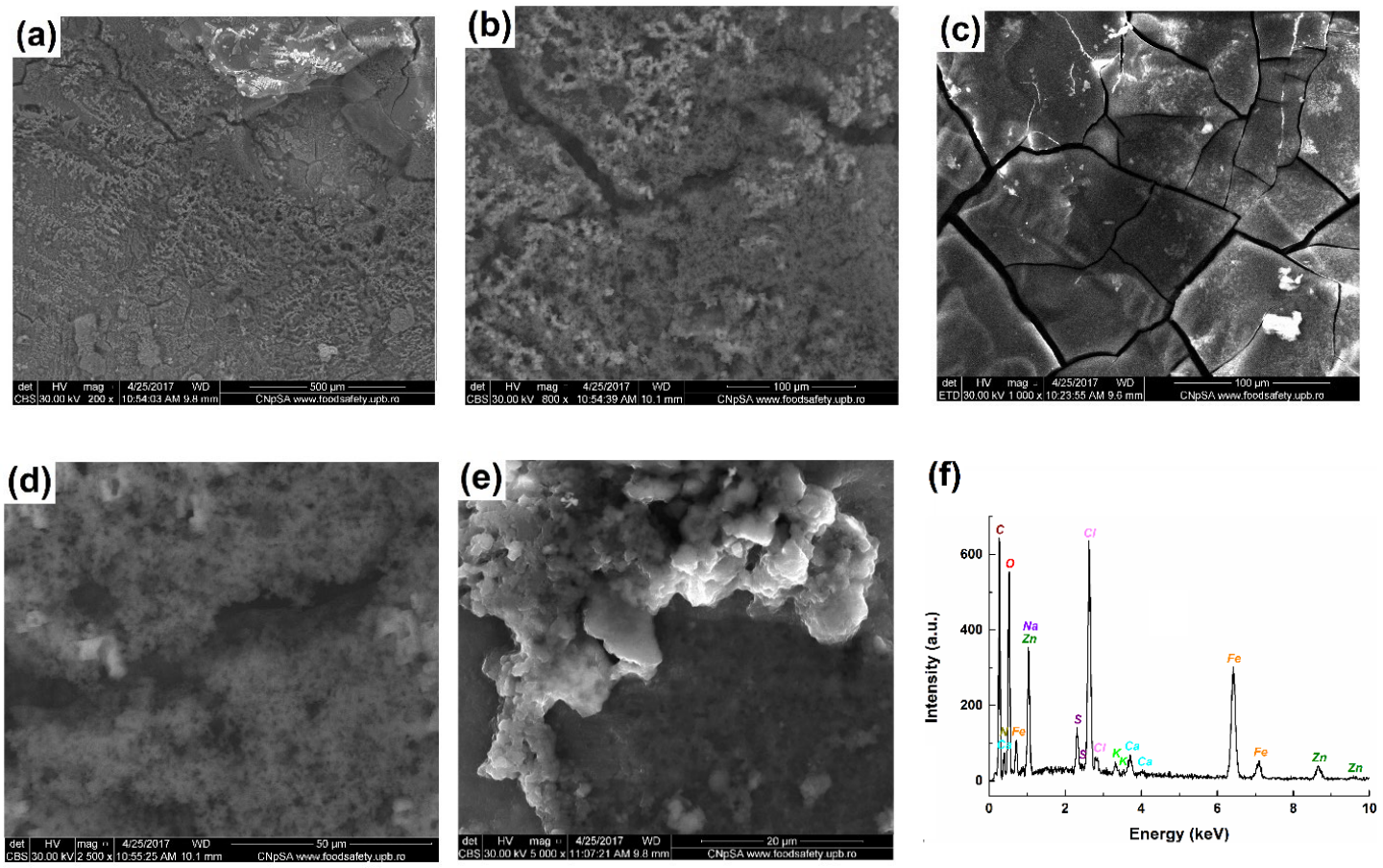

Figure 1. SEM micrographs of steel (sample 1) covered with corrosion products formed after exposure for 166 days in Fomtec (a-e); magnification from $\times 200$ (a) to $\times 5000$ (e); EDS spectrum showing elemental composition of corrosion products (f).

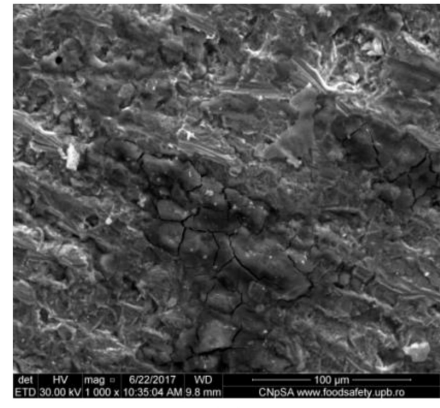

(a)

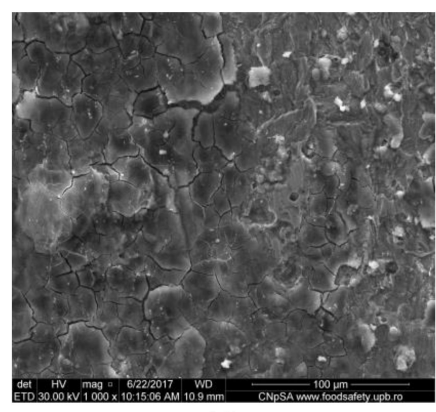

(d)

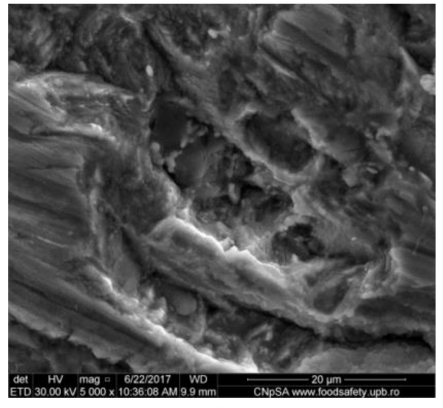

(b)

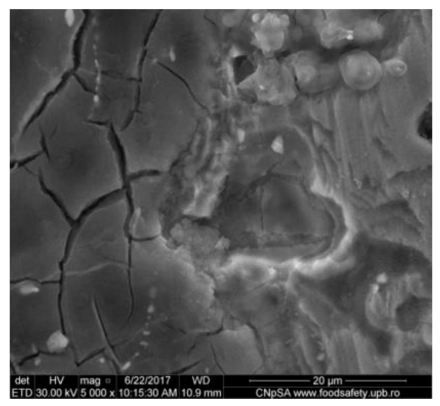

(e)

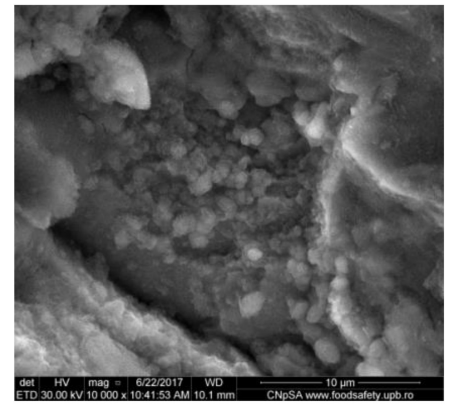

(c)

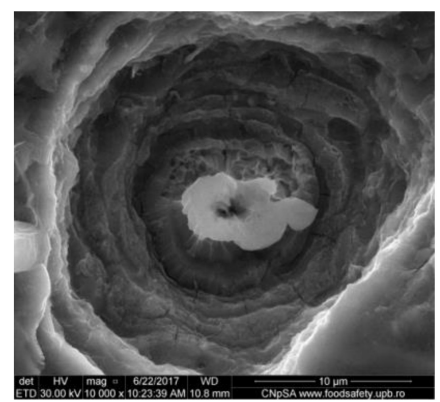

(f)

Figure 2. SEM micrographs (ETD images) of steel sample $1(\mathbf{a}-\mathbf{c})$ and steel sample $2(\mathbf{d}-\mathbf{f})$ after removing corrosion products formed after exposure 166 days in Fomtec; magnification from $\times 1000(\mathbf{a}, \mathbf{d})$ to $\times 10,000(\mathbf{c}, \mathbf{f})$.

The composition of the corrosion product layer imparts certain protective abilities and strongly influences the subsequent corrosion behavior of the steel. In the literature of corrosivity of firefighting foams containing proteins the information about the chemical nature of corrosion products formed onto carbon steel surface is still scarce. It was found the akaganeite $(\beta-\mathrm{FeOOH})$ layer as belt-like shaped crystallites for mild steel immersed in chloride containing aqueous environments [51,52]. Forms of other ferric oxyhydroxides, 
such as reddish-brown lepidocrocite $(\gamma-\mathrm{FeOOH})$ and goethite $(\alpha$-FeOOH fine crystallites with fibrous structure) were also reported as the main phases of corrosion layers together with $\mathrm{FeOCl}$ compound, and amorphous rust [53]. On contrary, an abundant literature has been published on corrosion of stainless steel in protein-containing media [54-58] whereas much less work has been dedicated to pure Fe $[55,59,60]$. For ferrous material surfaces, it is unanimously accepted that both physisorption and irreversible chemisorption of proteins may be possible and iron oxides formed on the surface will facilitate protein aggregation around the defect sites. Alternatively, it is possible for the protein to act as catalysts oxidizing the metal by their internal disulfate groups. Disulfide bonds in the new protein-metal complex compound may be subsequently reformed by oxidation with oxygen. This would also be the reason why contradictory findings are reported in the literature related to increasing or decreasing of corrosion attack in environments with protein content.

We have compared in our corrosion studies the chemical nature of the corroded products presents onto the surface to the bulk composition of steel. Thus, we can see the changes in chemical composition. Table 2 summarizes EDS data obtained for corrosion product formed on steel surface. Expectedly, we found a decrease in iron content in corrosion product layer (remained $5.65 \mathrm{wt} \%$ compared to about $99 \%$ in mild steel) and its significant enrichments in oxygen, carbon, nitrogen and chlorine, i.e., non-metallic elements as components of the oxide/hydroxide compounds or salts. Moreover, a preliminary X-ray diffraction analysis indicated that the corrosion products are mostly non-crystalline.

Table 2. The main elements detected by EDS in the corrosion product onto steel surface after 166-day immersion in Fomtec P 6\%.

\begin{tabular}{|c|c|c|c|c|c|c|c|c|c|c|}
\hline \multirow{2}{*}{$\begin{array}{l}\text { Chemical } \\
\text { Composition }\end{array}$} & \multicolumn{10}{|c|}{ Elements } \\
\hline & $\mathrm{Fe}$ & Mn & $S$ & $\mathrm{Ca}$ & $\mathrm{Na}$ & $\mathbf{K}$ & $\mathrm{C}$ & O & $\mathbf{N}$ & $\mathrm{Cl}$ \\
\hline$w t \%$ & 5.65 & 1.05 & 0.67 & 0.48 & 5.48 & 0.20 & 36.98 & 34.69 & 10.72 & 4.08 \\
\hline at $\%$ & 1.55 & 0.25 & 0.32 & 0.18 & 3.65 & 0.08 & 47.22 & 33.25 & 11.74 & 1.76 \\
\hline
\end{tabular}

\subsubsection{Corrosion of Al Alloy (AlSiCuMg Type)}

Only preliminary weight-loss experiments were performed regarding the gravimetric determination of corrosion rates for this cast $\mathrm{Al}$ alloy. We have tested three identical samples of $\mathrm{Al}$ alloy immersed 7 or 14 days in Fomtec and Profoam concentrates. Unfortunately, the obtained data of gravimetric index $(\mathrm{kg})$ and penetration rate index $C R$ (taking density value of alloy as $2.77 \mathrm{~g} / \mathrm{cm}^{3}$ ) in both protein concentrates were somewhat irrelevant and uncertain, in the sense that their weight-loss values were very different for each sample under identical conditions of immersion. Moreover, in many cases of profiled coupons, the removal of corrosion product by simple cleaning, brushing and washing (including rinsing with acetone) resulted in weight gain instead of weight loss. An explanation may be the existence of native aluminum oxide, a strong adherence of corrosion products and a pore filling process. We mention that the native aluminum oxide was not intentionally removed in the sample preparation to simulate the conditions in practice.

The weight losses reached almost constant values after 14 days of immersion of $\mathrm{Al}$ alloy, with calculated average corrosion rates of $0.914 \pm 0.147 \mathrm{mdd}(0.474 \pm 0.076 \mathrm{mipy})$ in Fomtec and $2.107 \pm 0.425 \mathrm{mdd}(1.093 \pm 0.214 \mathrm{mipy})$ in Profoam. However, it is worth mentioning that we also preliminarily weighed the samples after 7 days of immersion, and the determined average corrosion rates were $0.184 \pm 0.027 \mathrm{mdd}(0.095 \pm 0.014 \mathrm{mipy})$ in Fomtec and $0.283 \pm 0.050 \mathrm{mdd}(0.147 \pm 0.026$ mipy $)$ in Profoam. These surprising results can indicate increased corrosion only after long exposure time. We may suppose that the slow processes of chemical dissolution or chemical conversion of the native aluminum oxide film during the first few days are followed by intense attack that produces a non-protective layer of corrosion products. The corrosion of $\mathrm{Al}$ alloy may be considered to advance over time, and therefore, the values of gravimetric index and penetration rate indicate non-stable 
behavior of aluminum alloy in contact with the protein foam concentrate for a long time. Thus, we have demonstrated the aggressiveness of the foam concentrates on nozzles or Storz couplings made by cast aluminum alloy. Bertschy et al. [2] reported a corrosion rate of 1-3 mdd for 6061 aluminum alloy in contact with a light water concentrate, also proving that $\mathrm{Al}$ alloy has the best corrosion resistance to all other foam agents investigated. Sheffey and Wright [3] determined for $6061 \mathrm{Al}$ alloy a penetration rate of $0.03-0.15$ mipy which was much lower than for UNS G 10,100 steel or 304 stainless steel.

SEM images obtained for the initial aluminum alloy samples have illustrated interdendritic arrangement of silicon in the solid solution based on $\mathrm{Al}$, and the existence of insoluble iron leading to acicular or polyhedral morphology. The quite uniform presence of $\mathrm{Al}, \mathrm{Si}, \mathrm{Fe}$ and $\mathrm{Cu}$ in alloy was identified in the EDS maps proving that the manufacturing company processed the $\mathrm{Al}$ alloy by appropriate heat treatments. Examples of the states of the cleaned surfaces after immersion of the $\mathrm{Al}$ alloy in Fomtec for $366 \mathrm{~h}$ and the alloy in Profoam for $350 \mathrm{~h}$ are shown, respectively, in Figures 3 and 4, indicating that a part of the corrosion products remained as an adherent layer. Therefore, the morphology of corroded samples varied quite a lot based on the selection of the area for the microscopy, although the exposure conditions in the aggressive foam concentrate were the same. It can be clearly observed that large aggregates of corrosion products remained on some metal areas and their visible cracks. From the anticorrosion protection point of view, this is a drawback, meaning that the corrosion products deposited do not protect. In most cases, the $\mathrm{Al}$ alloy surface exposed in Profoam was much more corrosively attacked than in Fomtec, evidenced by more intense localized corrosion, deeper pits and caverns.

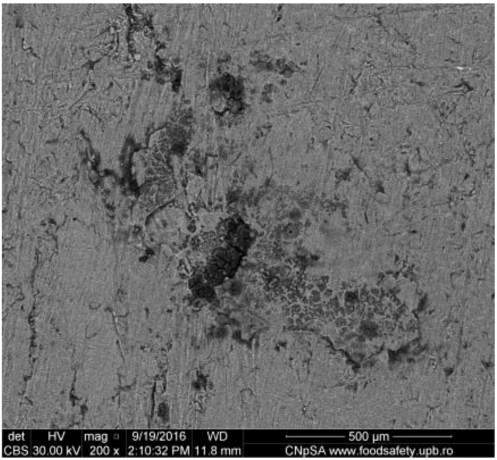

(a)

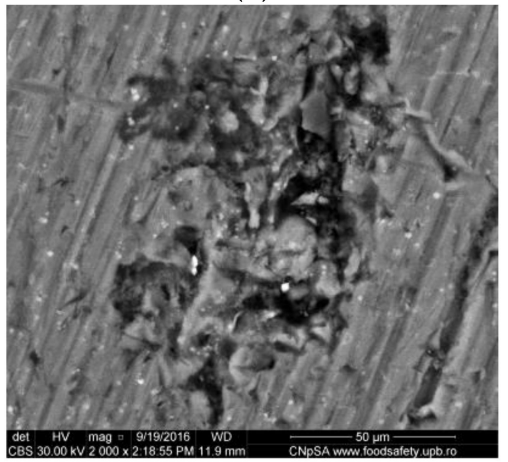

(d)

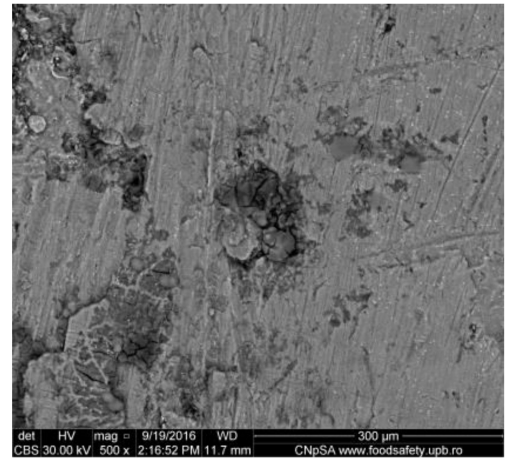

(b)

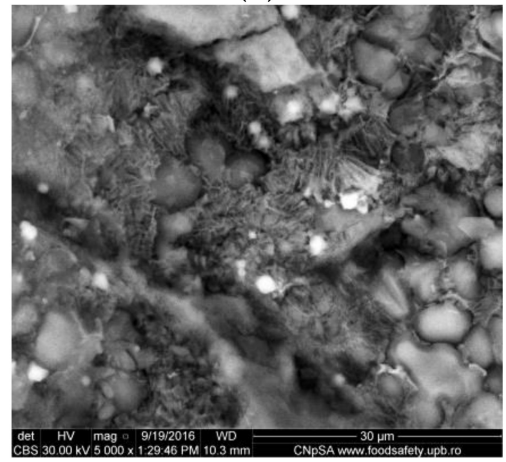

(e)

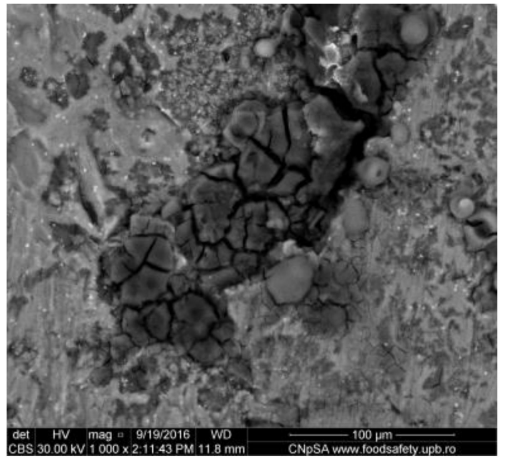

(c)

Figure 3. SEM micrographs (CBS images) of AlSiCuMg alloy corroded for 14 days in Fomtec after removing corrosion products; magnification $(\mathbf{a}) \times 200 ;(\mathbf{b}) \times 500 ;(\mathbf{c}) \times 1000 ;(\mathbf{d}) \times 2000 ;(\mathbf{e}) \times 5000$. 


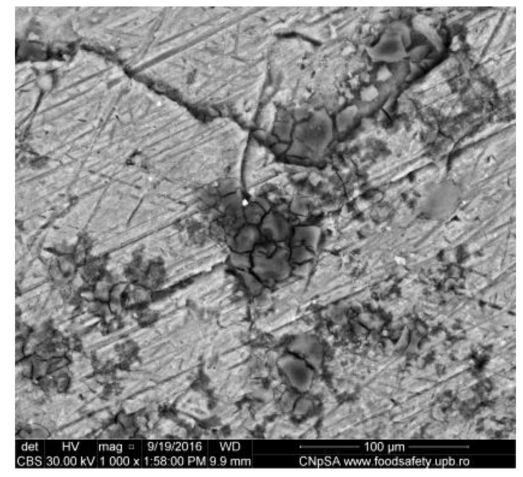

(a)

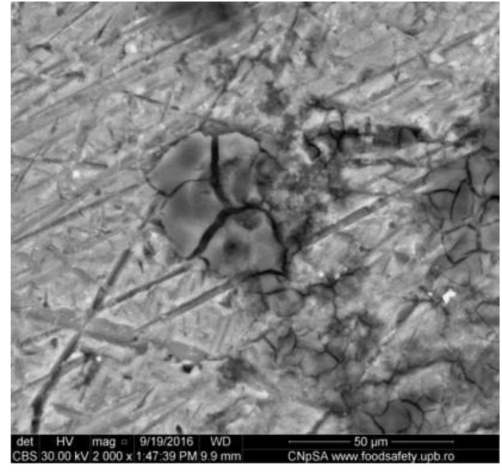

(b)

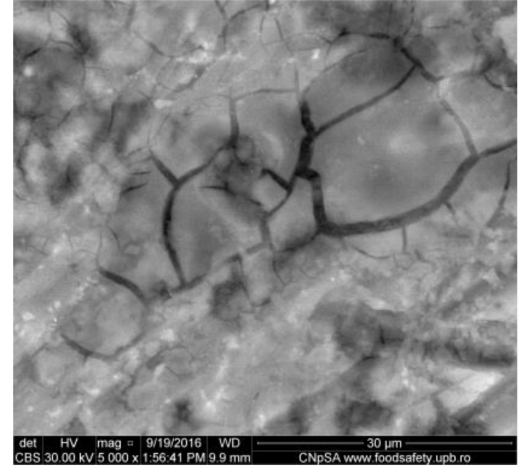

(c)

Figure 4. SEM micrographs (CBS images) of AlSiCuMg alloy corroded for 14 days in Profoam after removing corrosion products; magnification from $(\mathbf{a}) \times 1000 ;(\mathbf{b}) \times 1000 ;(\mathbf{c}) \times 5000$.

If the composition of the corrosion products (indicated in EDS spectra, Figure 5 and Table 3) is compared with the composition of $\mathrm{Al}$ alloy, the changes can be observed for all concentrations of the constituent elements. Thus, $\mathrm{Al}$ content decreased drastically from $77 \%$ to $35-40 \%$, while silicon, which had a maximum of $13 \%$ in the alloy, had a variable concentration in the corrosion product-more than double the content $(33 \%)$ after exposure to Fomtec and very low content (4\%) after corrosion in Profoam. The contents of $\mathrm{Cu}, \mathrm{Fe}$ and Mn decreased significantly. There are also elements such as oxygen (26-30\%), carbon ( $21 \%$ for sample corroded in Profoam) and chlorine (around 1\%) that were constituents of the corrosion products.
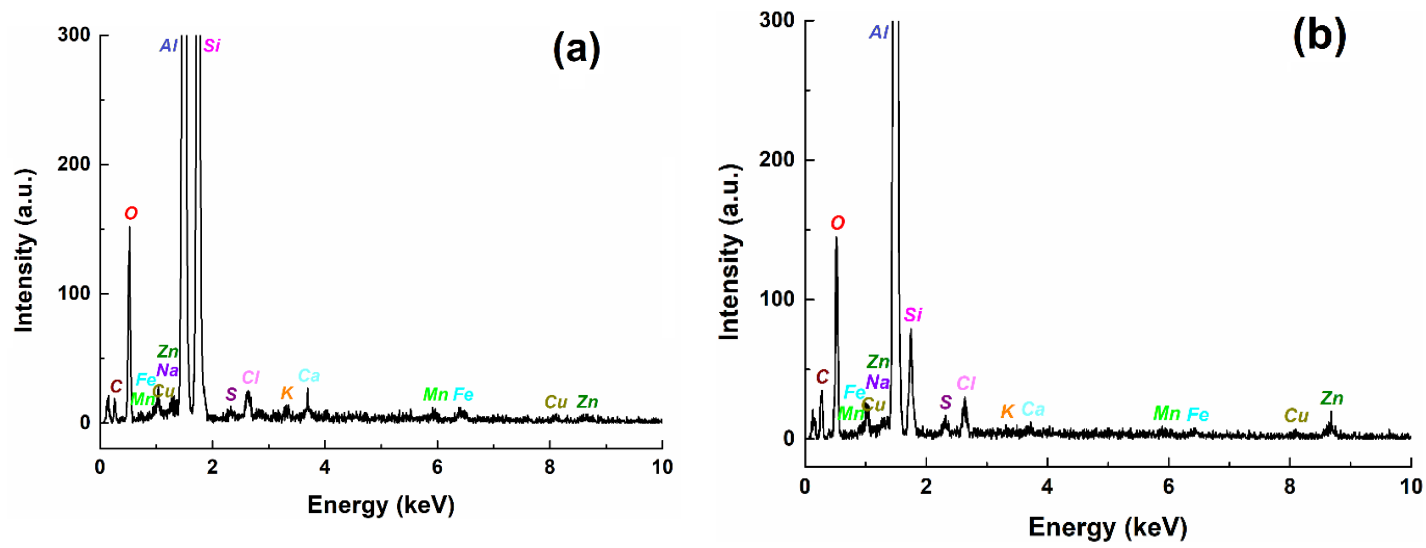

Figure 5. EDS spectra for corrosion products formed by corrosion of AlSiCuMg alloy for 14 days: in Fomtec (a) and in Profoam (b).

Table 3. The main elements detected by EDS in the corrosion products on the $\mathrm{Al}$ alloy surface after immersion for 14 days in Fomtec or Profoam.

\begin{tabular}{|c|c|c|c|c|c|c|c|c|c|c|c|c|c|}
\hline \multirow{2}{*}{$\begin{array}{l}\text { Chem. } \\
\text { Compos. }\end{array}$} & \multicolumn{13}{|c|}{ Elements } \\
\hline & $\mathrm{Al}$ & Si & $\mathrm{Cu}$ & $\mathrm{Fe}$ & Mn & $\mathrm{Zn}$ & $\mathrm{Ca}$ & $\mathrm{Na}$ & K & $\mathrm{S}$ & $\mathrm{C}$ & $\mathrm{O}$ & $\mathrm{Cl}$ \\
\hline \multicolumn{14}{|c|}{ Corroded $\mathrm{Al}$ alloy in Fomtec } \\
\hline $\mathrm{wt} \%$ & 35.25 & 33.92 & 0.35 & 0.54 & 0.39 & 0.46 & 0.51 & 0.49 & 0.26 & 0.34 & - & 26.20 & 1.28 \\
\hline at $\%$ & 30.61 & 28.29 & 0.13 & 0.23 & 0.17 & 0.17 & 0.30 & 0.50 & 0.16 & 0.25 & - & 38.37 & 0.85 \\
\hline \multicolumn{14}{|c|}{ Corroded Al alloy in Profoam } \\
\hline$w t \%$ & 40.90 & 4.40 & 0.47 & 0.33 & 0.48 & 1.28 & - & 0.33 & - & 0.47 & 20.95 & 29.42 & 0.98 \\
\hline at $\%$ & 28.31 & 2.93 & 0.14 & 0.11 & 0.16 & 0.37 & - & 0.27 & - & 0.28 & 32.58 & 34.34 & 0.52 \\
\hline
\end{tabular}




\subsection{Studies of the Accelerated Corrosion Using Electrochemical Methods}

The electrochemical corrosion tests were carried out to confirm that the weight loss data obtained are reliable. Plotting the potentiodynamic polarization curves and electrochemical impedance spectra represents a very useful procedure with which to evaluate the corrosion parameters within a short period of time [61]. Semi-logarithmic potentiodynamic polarization curves (Tafel plots) were recorded in a potential range around the free-corrosion potential (open-circuit potential $\mathrm{OCP}$ ), generally by first polarizing the electrode $200-400 \mathrm{mV}$ more cathodic and then $800-1000 \mathrm{mV}$ more anodic. Values of corrosion potential and corrosion current were determined graphically from the intercept of the anodic and cathodic Tafel lines plotted from both branches of polarization curve. The corrosion current density $\mathrm{I}_{\text {corr }}\left(\mu \mathrm{A} / \mathrm{cm}^{2}\right)$ can be converted to penetration corrosion rate $C R$ (in mipy) by using Equation (1) based on Faraday's law:

$$
C R=\frac{8760 \times 10^{-6} \times 10^{3}}{26.8 \times 2.54} \cdot \frac{I_{\text {corr }} M}{n \rho}=0.12868 \frac{I_{\text {corr }} M}{n \rho}
$$

where $M$ is the atomic weight of specimen $(55.85 \mathrm{~g} / \mathrm{mol}$ for Fe and $26.98 \mathrm{~g} / \mathrm{mol}$ for $\mathrm{Al}), \mathrm{n}$ is the number of electrons transferred in the corrosion reaction $(n=2$ for Fe and $n=3$ for $\mathrm{Al}$ ) and $\rho$ is the density $\left(\mathrm{g} / \mathrm{cm}^{3}\right)$ of the metal specimen. Remember that our working electrode had a $1 \mathrm{~cm}^{2}$ surface area exposed.

The Nyquist diagrams (graphical representation of imaginary impedance vs. real impedance) and Bode diagrams (graphical representation of phase angle vs. frequency) were plotted at OCP and various anodic potentials. The Nyquist semicircle diameter represents polarization resistance $\mathrm{Rp}$ which is inversely proportional to corrosion current. Applied anodic polarization was considered sufficient to illustrate the changes of corrosion behavior (corrosion current) that the metallic electrode underwent each time in fresh foam concentrate. Checking the validity of the electrochemical impedance spectroscopy data was performed by modeling with Randles type equivalent electrical circuit (Figure 6). In this circuit, Rs represents the ohmic resistance (uncompensated resistance) of the solution between the working electrode and auxiliary electrode. Rs was in series with a parallel circuit of an interface capacity and a resistance (the polarization resistance $R p$ ) corresponding to the charge transfer in the corrosion process. Due to the presence of surface roughness and non-homogeneities of the coupon surfaces, a constant phase element CPE was used instead of a pure capacitor. CPE has the components CPE-T (capacitive element) and CPE- $p$ (exponent representing the deviation from an ideal capacitor, for which CPE- $p$ equals 1 ).

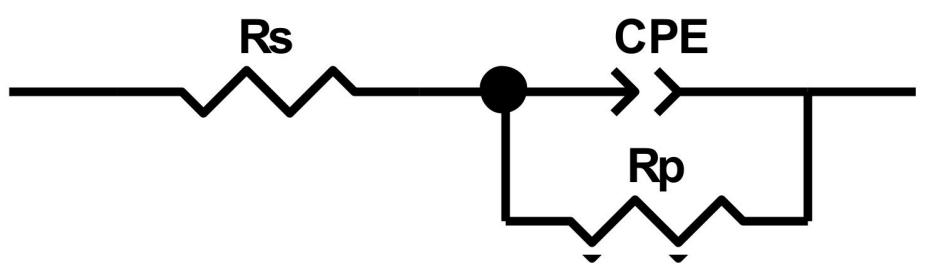

Figure 6. The equivalent electrical circuit proposed for modeling corrosion processes, with polarization resistance Rp as Faradaic impedance.

\subsubsection{Polarization Curves and EIS Spectra of Carbon Steel}

Flat steel plates were prepared from the walls, bottoms or lids of containers where Fomtec and Profoam foam concentrates are stored. Figure 7 presents potentiodynamic polarization curves for tested carbon steel samples in both investigated concentrates from which corrosion potential (Ecorr) and corrosion current density (Icorr) were determined graphically for each coupon. 

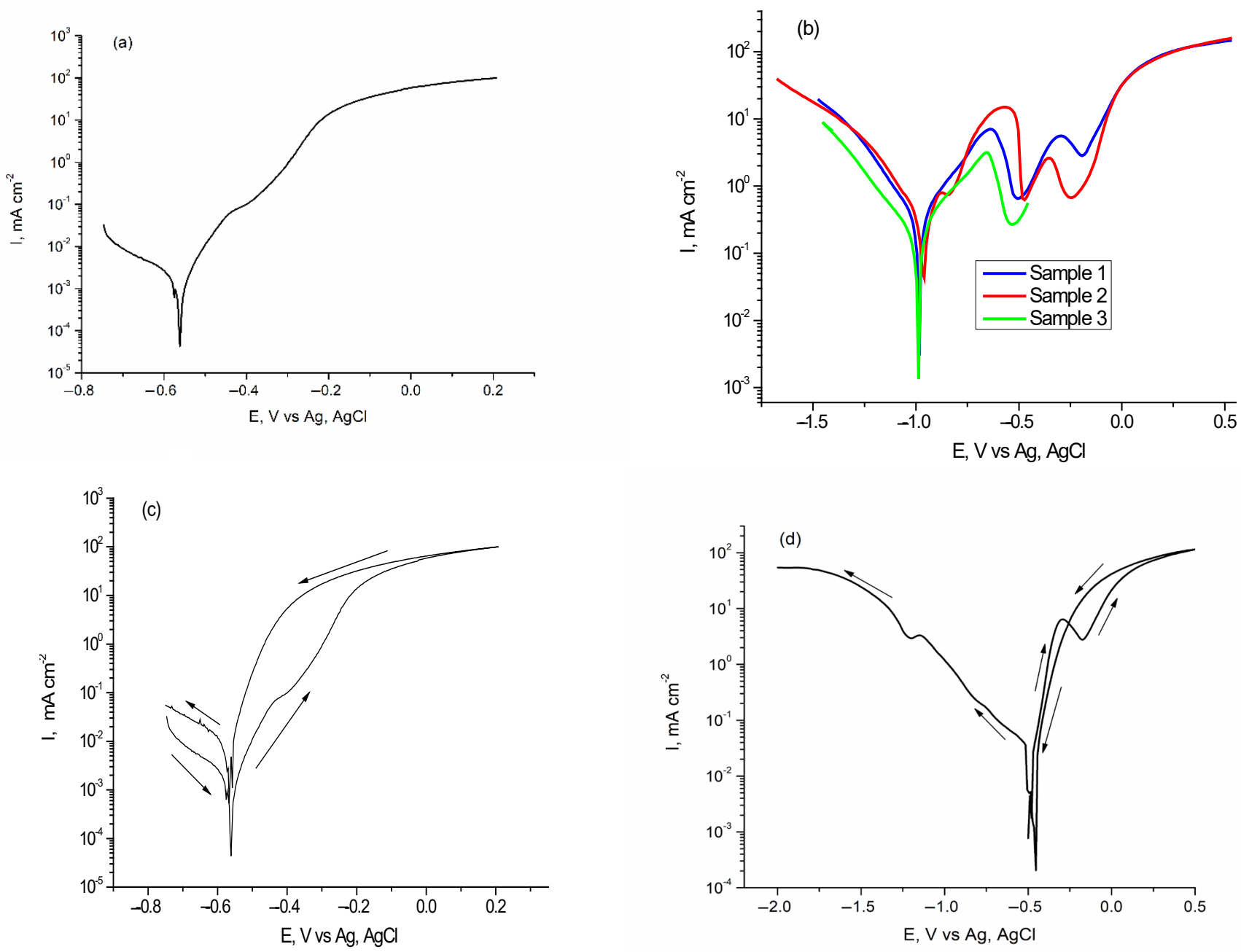

Figure 7. Potentiodynamic polarization of $42.2 \mathrm{k}$ steel samples immersed at room temperature in Fomtec (a) and in Profoam (b); cyclic polarization of steel in Fomtec (c,d).

By scanning the electrode potential in the cathodic direction, the curves reproduced themselves quite accurately and correspond to the electrochemical reduction of the atmospheric $\mathrm{O}_{2}$ molecules dissolved in the liquid. However, on the anodic branches, which correspond to the steel corrosion processes, there are clearly differences in the behavior of the samples. In steel/Fomtec system an active corrosion zone is observed in the beginning of curve (Figure 7a) due to the acceleration of iron dissolution caused by the strong action of proteins and inorganic compounds contained. This is followed by a fairly narrow range of constant current around the potential of $-400 \mathrm{mV}$, after which the current increases again until it reaches a stationary state of constant and significant corrosion. Therefore, steel passivation was not observed in this system. In Profoam (Figure 7b), after the active corrosion zone, it followed a steady state characterized by sinusoidal variations of the current assigned to periodic processes of formation/detachment of adsorbed layers on the electrode. In this potential range the current has a decrease of at least an order of magnitude (a sinusoid minimum of $c a 0.3 \mathrm{~mA} / \mathrm{cm}^{2}$ can be seen on logarithmic scale), indicating temporary passivation due to the deposition of corrosion products. The process was clearly reproducible for all samples immersed in Profoam. The final anodic polarization led to a current that was almost constant, limiting the current characteristics of the systems that have a mechanism of diffusional control corrosion. Curves recorded by cyclic polarization (Figure $7 \mathrm{c}, \mathrm{d}$ ) show that when returning the potential scan, no other processes were observed along with the corrosion (in anodic branch) and oxygen reduction (in cathodic branch). Smaller hysteresis area during descending the anodic current indicates a lower 
pitting attack. Table 4 lists the corrosion parameters determined from Tafel polarization curves. Corrosion rate, calculated as penetration rate (mipy) using Equation (1), is included. Although penetration was of an order of magnitude larger than the $C R$ values determined by the gravimetric method (Table 1), these data obtained by accelerated method confirm the greater aggressiveness of the Profoam concentrate on carbon steel in the short time (half an hour) in which the electrochemical measurements were performed.

Table 4. Corrosion parameters determined from potentiodynamic polarization curves of steel in foam concentrates.

\begin{tabular}{|c|c|c|c|c|}
\hline $\begin{array}{l}\text { Corrosion System: } \\
\text { Steel/Foam Agent }\end{array}$ & $\begin{array}{c}\text { OCP, } \\
\mathrm{mV}\end{array}$ & $\begin{array}{c}\text { Ecorr vs. Ag/AgCl, } \\
\mathrm{mV}\end{array}$ & $\begin{array}{c}\text { Icorr, } \\
\mu \mathrm{A} / \mathrm{cm}^{2}\end{array}$ & $\begin{array}{l}C R, \\
\text { mipy }\end{array}$ \\
\hline Sample 1 in Fomtec & -526 & -561 & 43.5 & 19.887 \\
\hline Sample 2 in Fomtec (cyclic) & -538 & -566 & 48.2 & 22.036 \\
\hline Sample 3 in Fomtec (cyclic) & -501 & -538 & 64.6 & 29.533 \\
\hline Average: & & & $52.1 \pm 10.98$ & $23.818 \pm 5.06$ \\
\hline Sample 1 in Profoam & -862 & -984 & 194 & 88.690 \\
\hline Sample 2 in Profoam & -887 & -929 & 238 & 108.806 \\
\hline Sample 3 in Profoam & -865 & -987 & 172 & 78.633 \\
\hline Average: & & & $201.3 \pm 33.60$ & $92.043 \pm 15.36$ \\
\hline
\end{tabular}

Figure 8 shows a series of electrochemical impedance spectra recorded for $42.2 \mathrm{k}$ steel samples in Profoam foam concentrate. Starting from the OCP, which has the value $-865 \mathrm{mV}$ vs./ $\mathrm{AgCl}$, various EIS spectra for more and more anodic polarization up to overvoltage of $430 \mathrm{mV}$ were performed. For each Nyquist curve in Figure 8a, we observed an imperfect depressed capacitive semicircle which has at its end (at low frequencies) a linear portion, a "tail," which can be attributed to the formation of a film on the electrode surface. A horizontal line would indicate an unstable film, suggesting a layer of corrosion products that periodically come off or are soluble in the electrolyte (unstable passivation). At high anodic polarization, the semicircles tend to have a worm-like, twisted inward shape, meaning that the corrosion products formed are more strongly adsorbed. However, the main feature of semicircle diameter (i.e., polarization resistance $R_{p}$ ) is the existence of two trends of variation with anodic polarization: (i) at potentials between -865 and $-835 \mathrm{mV}$ a fluctuant value of the diameter $\left(500-700 \Omega \mathrm{cm}^{2}\right)$ is observed, proving an active corrosion; (ii) in the range of large polarization from $-825 \mathrm{mV}$ to $-435 \mathrm{mV}$, the sudden growth of the diameter suggests a substantially diminished corrosion due to passivation. The phase angle-frequency dependence showed by Bode diagrams exhibits each time a single maximum phase angle. Almost constant value around $-70^{\circ}$ at low anodic polarization (including $-835 \mathrm{mV}$ ) indicates strong barrier properties of the surface oxide as semiconductor corrosion products deposited on the steel's surface. Recall that a maximum angle of $-90^{\circ}$ corresponds to an ideal electrical insulator. One might think that the film is always quite compact, but at the final high anodic polarizations of -825 and $-435 \mathrm{mV}$, the maximum angle decreased gradually to $-55^{\circ}$, which suggests less electric insulation, confirming an instable non-protecting layer. 

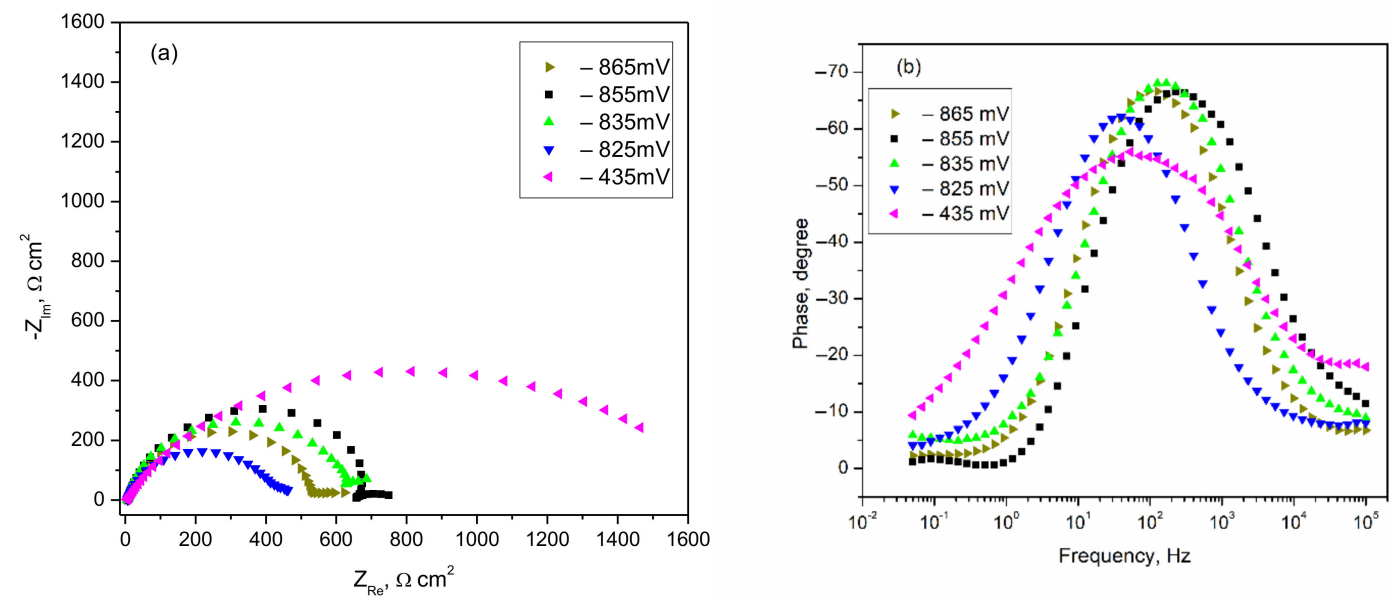

Figure 8. Nyquist spectra (a) and Bode phase angle spectra (b) for steel in Profoam at various electrode potentials starting from $-865 \mathrm{mV}(\mathrm{OCP})$.

The numerical results obtained by best fitting corrosion data on the presented model are listed in Table 5 and indicate plausible values for all cases of anodic polarization. The most reliable results are for the ohmic resistance of solution $R s$, where the values are reproducible-most being in narrow range of $5.9-6.8 \Omega \mathrm{cm}^{2}$. The $C P E-T$ parameter indicating the capacity of the electrical double layer has values $23-200 \mu \mathrm{F} / \mathrm{cm}^{2}$ which correspond to the usual range for double layer of metals in aqueous solutions. However, the steel/Profoam electrolyte interface behaved almost non-ideally, with the exponent $C P E-p$ of $0.66-0.89$ (less than 1). Although the evolution of the polarization resistance $R p$ during anodic polarization had some fluctuations, an active corrosion zone for polarization up to $-825 \mathrm{mV}$ can be suggested, followed by passivation illustrated by much higher values of Rp.

Table 5. Values of equivalent circuit parameters for corrosion of $42.2 \mathrm{k}$ steel in Profoam concentrate.

\begin{tabular}{ccccc}
\hline $\begin{array}{c}\text { Anodic } \\
\text { Polarization, } \mathbf{m V}\end{array}$ & $\boldsymbol{R s}, \mathbf{\Omega} \mathbf{c m}^{2}$ & $\begin{array}{c}C P E-T, \\
\mu \mathrm{F} / \mathbf{c m}^{2}\end{array}$ & $\begin{array}{c}C P E 1-p \\
\text { Exponent }\end{array}$ & $\boldsymbol{R} \boldsymbol{p}, \mathbf{\mathbf { c m } ^ { 2 }}$ \\
\hline-865 & 7.2 & 48.54 & 0.875 & 550 \\
\hline-855 & 6.8 & 23.33 & 0.862 & 699 \\
\hline-845 & 6.4 & 29.83 & 0.890 & 526 \\
\hline-835 & 6.4 & 126.49 & 0.746 & 605 \\
\hline-825 & 7.7 & 177.33 & 0.825 & 439 \\
\hline-795 & 5.9 & 41.29 & 0.852 & 1180 \\
\hline-435 & 5.1 & 204.44 & 0.664 & 1558 \\
\hline
\end{tabular}

Our experimental results are consistent with the literature illustrating how the presence of proteins accelerates or decreases the steel corrosion. It has been shown by drawing cyclic polarization curves [54] that proteins such as transferrin, fibrinogen, gamma-globulin and albumin (all from bovine serum) increase in that order the corrosion of both 304 and 316L stainless steels in Hank human simulated fluid. Increases in anodic current density and intensification of the release of metal ions were observed. Acting as complexing agents, the proteins stimulate the metal dissolution and suppress the formation of a protective oxide layer. Corrosion for six different types of stainless steels in a cellular fluid, which had a same protein composition as the skeletal muscle, was investigated by Rojas and Lago [55]. Anodic polarization plots and cyclic polarization curves suggested a chemosorbed layer on the stainless steel consisted of a mixture of metal oxides and proteins. It seems to be a more unstable passive layer than that formed in protein-free solutions; the pitting corrosion 
was also observed. Tafel curves revealed a diffusion of protein control process of the corrosion mechanism. Atapour et al. [58] investigated corrosion of austenitic (AISI 316 L), ferritic (AISI 430) and lean duplex (LDX 2101) stainless steels used in the dairy industry. Potentiodynamic polarization curves and EIS spectra were recorded for simulated milk and whey protein isolate. All steel grades revealed low corrosion rates in the whey protein solution without any sign of active/metastable corrosion. A severe pitting corrosion was evident for 430 steel in simulated milk, whereas no pitting was taking place for either 316L or 2101 steel. The Nyquist diagram recorded by these authors clearly demonstrated the highest passivity for 2101 steel, followed by $316 \mathrm{~L}$ and 430 steel, in both food solutions. The maximum phase angle approaching $-80^{\circ}$ indicated that the barrier layer formed during corrosion hinders the migration of aggressive species, such as $\mathrm{O}^{2-}$ and $\mathrm{Cl}^{-}$, from the solution into the steel/solution interface. The influence of bovine serum albumin (BSA) and lysozyme on pure Fe behavior [59] has been studied in simulated body fluid (SBF). The authors observed intense corrosion explained by electrostatic interactions between different species of electrically charged oxide/hydroxide, newly formed on the electrode, and protein molecules existing in solution or adsorbed. However, it is worth mentioning that contradictory findings have been reported in the literature related to increasing or decreasing of corrosion in fluids containing proteins. For instance, Geringer et al. [56] recorded EIS spectra for 316L stainless steel in Ringer and $\mathrm{NaCl}$ solutions at different anodic polarizations and found that albumin at concentrations of up to $20 \mathrm{~g} / \mathrm{L}$ positively influences (in the sense of diminished corrosion) the stability of steel. By adding the casein natural protein in $\mathrm{HCl}$ solution, other authors $[62,63]$ found casein to inhibit the corrosion of both mild steel and 316L stainless steel.

\subsubsection{Polarization Curves and EIS Spectra of AlSiCuMg Alloy}

We showed that aluminum alloy samples were taken by cutting profiled coupons from different nozzles used for spraying the foam or Storz couplings for hoses. Potentiodynamic polarization curves recorded in both investigated foam concentrates are presented in Figure 9 and were processed by the usual graphical procedure to determine the corrosion potential (Ecorr) and corrosion current density (Icorr).

In Figure 9, the branches of polarization curves at the most negative potentials (left) correspond to the cathodic reduction of dissolved oxygen. The oxygen molecules existed in solution because no deaeration (not bubbling with argon or pure nitrogen) was performed. It is possible to have a certain amount of absorbed reactive atomic hydrogen produced by the humidity in the environment [44,45], as discussed in the Introduction.

The anodic potential scanning (right branch) illustrates the processes during $\mathrm{Al}$ alloy corrosion in foam concentrate, with an active corrosion region starting from the opencircuit potential. The shapes are almost identical for both concentrates (Figure 9a,b) with the current density sharply increasing and then showing a current limitation within a potential range from -300 to $+1800 \mathrm{mV}$. The active-passive transition was not clearly observed, although for Profoam we recorded small oscillations of anodic current in the active corrosion region between -600 and $-500 \mathrm{mV}$. The wide region of limited current at high anodic potentials corresponds to a steady state in which corrosion occurred intensely and continuously, but the current value was kept constant due to a stationarity created between the amount of newly formed corrosion products which remained as the adsorbed layer and non-adherent products which fell (or dissolve) into solution. Scanning back the potential in cyclic polarization (Figure $9 \mathrm{c}-\mathrm{e}$ ) showed no other processes along with the corrosion of $\mathrm{Al}$ alloy (in anodic branch) and oxygen reduction (in cathodic branch).

Values of corrosion parameters determined for $\mathrm{Al}$ alloy immersed in foam concentrates are summarized in Table 6. It can be observed that Profoam is more aggressive against an aluminum alloy because the corrosion rate (expressed as Icorr and $C R$ ) is almost four times higher than that of Fomtec. The greater aggressiveness of Profoam also corresponds to what we found in the potentiodynamic polarization experiments for steel/foam concentrates 
systems. However, on the whole, the corrosive attacks of both foam agents were an order of magnitude lower for $\mathrm{Al}$ alloy than for $42.2 \mathrm{k}$ steel.
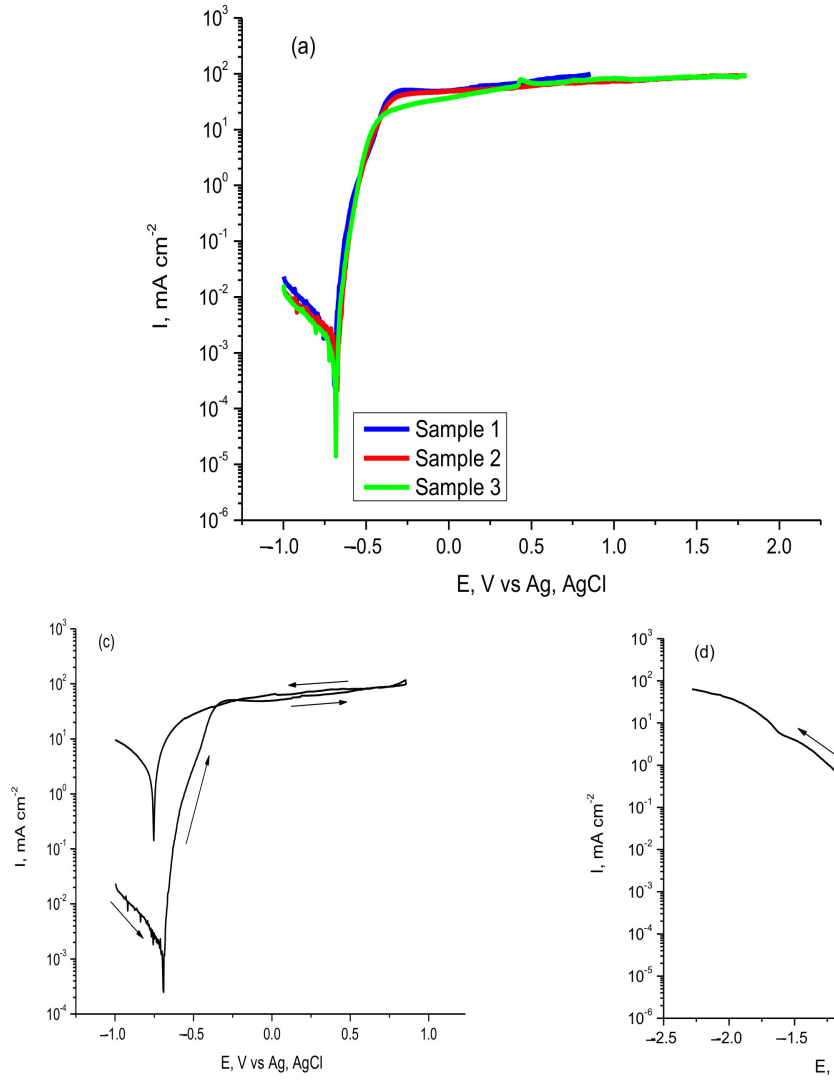
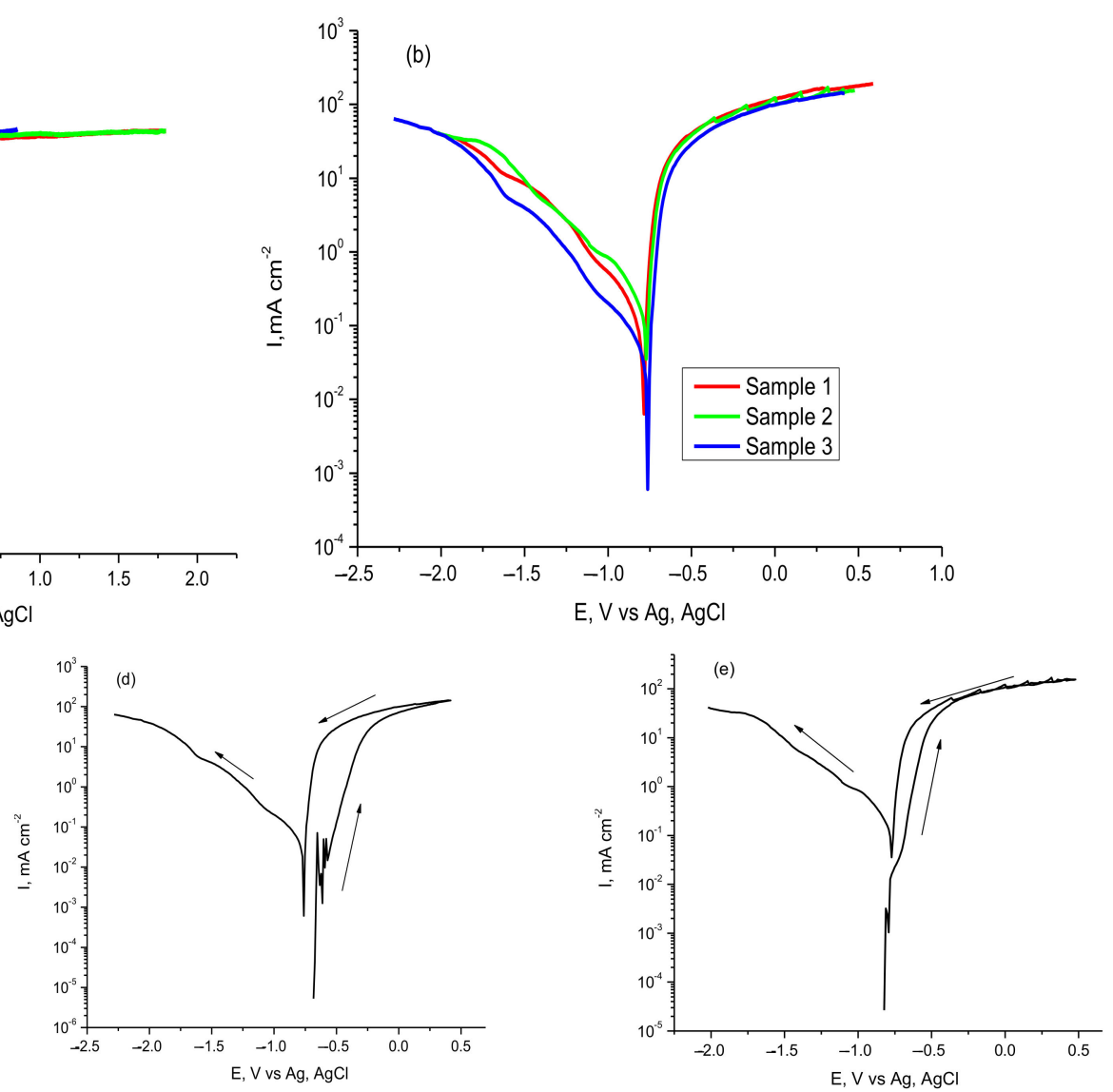

Figure 9. Comparative Tafel polarization curves for AlSiCuMg alloy in Fomtec (a) and in Profoam (b); cyclic polarization of Al alloy in Fomtec (c) and in Profoam (d,e).

Our results can be interpreted according to various investigations reported in literature. The effect of proteins on the corrosion of pure Al powder has been studied by Clark et al. [64], who found that the corrosion process in Ringer solution or $\mathrm{NaCl}$ solution is not significantly influenced by adding serum albumin or fibrinogen. In our experiments, the presence of proteins in the foam concentrate would have been responsible for the corrosion of $\mathrm{Cu}$ (a component with a high concentration in our AlSiCuMg alloy) rather than of the aluminum component, which is a highly passivated metal. Therefore, the attack probably became more intense than for pure aluminum metal, with the formation of globular corrosion products [65]. In our study of $\mathrm{Al}$ alloy behavior, its corrosion may be also correlated with the existence of few particles of intermetallic compounds (IM). IM particles are generally considered to be sites of localized corrosion initiation, due to the appearance of galvanic couples between the IM and the metal oxides that surround them. For example, it has been suggested [66] that the $(\mathrm{Al}, \mathrm{Cu})_{x}(\mathrm{Fe}, \mathrm{Mn})_{\mathrm{y}} \mathrm{Si}$ intermetallic compound appears in the AA2024-T3 alloy, together with other modified forms of intermetallic compounds of the types $\mathrm{Al} 8 \mathrm{Fe} 2 \mathrm{Si}$ or $\mathrm{Al} 10 \mathrm{Fe} 2 \mathrm{Si}$. 
Table 6. Corrosion parameters determined from potentiodynamic polarization curves of $\mathrm{Al}$ alloy in foam concentrates.

\begin{tabular}{|c|c|c|c|c|}
\hline $\begin{array}{l}\text { Corrosion System: Al } \\
\text { Alloy/Foam Agent }\end{array}$ & $\begin{array}{l}\text { OCP, } \\
\mathrm{mV}\end{array}$ & $\begin{array}{c}\text { Ecorr vs. Ag/AgCl, } \\
\text { mV }\end{array}$ & $\begin{array}{c}\text { Icorr } \\
\mu \mathrm{A} / \mathrm{cm}^{2}\end{array}$ & $\begin{array}{l}C R, \\
\text { Mipy }\end{array}$ \\
\hline Sample 1 in Fomtec & -705 & -695 & 1.45 & 0.606 \\
\hline Sample 2 in Fomtec & -680 & -677 & 1.93 & 0.806 \\
\hline Sample 3 in Fomtec & -676 & -677 & 1.32 & 0.551 \\
\hline Average: & & & $1.57 \pm 0.321$ & $0.654 \pm 0.134$ \\
\hline Sample 1 in Profoam & -745 & -747 & 10.0 & 4.178 \\
\hline Sample 2 in Profoam & -729 & -713 & 7.1 & 2.966 \\
\hline Sample 3 in Profoam & -776 & -781 & 9.1 & 3.802 \\
\hline Sample 4 in Profoam & -705 & -702 & 6.3 & 2.632 \\
\hline Average: & & & $8.12 \pm 1.717$ & $3.394 \pm 0.718$ \\
\hline
\end{tabular}

Figure 10 presents a series of EIS spectra obtained by gradual anodic polarization of Al alloy in Profoam. Simple capacitive Nyquist semicircles were observed for the first three polarizations near OCP (Figure 10a). At stationary potential the diameter of semicircle is around $25,000 \Omega \mathrm{cm}^{2}$ and then decreases to a few thousand $\Omega \mathrm{cm}^{2}$, indicating an extension of the induction time for the active corrosion zone. Nyquist semicircles at higher anodic polarization levels (Figure 10b,c) have a worm shape, characteristic of corrosion with the formation of insoluble products that are adsorbed on the electrode. Their diameters have values that still decrease gradually with anodic overpotential, confirming the more and more intense corrosion of the $\mathrm{Al}$ alloy. In the Bode diagrams of the phase angle vs. frequency, a single maximum phase angle is shown each time. Figure $10 \mathrm{~d}$ exhibits a wide frequency range for a Bode curve, in which the maximum phase angle of $-80^{\circ}$ is maintained (including $-690 \mathrm{mV}$ polarization), which indicates strong electrical insulation of the surface due to native aluminum oxide which has not yet been corroded. This is in agreement with weight-loss data. Figure 10e,f shows a drastic decline in the maximum phase angle, from $-70^{\circ}$ to $-13^{\circ}$, confirming a continuous corrosion process and the formation of a porous layer with less and less protection against corrosion.

The quantitative results of the best spectra fitting are provided in Table 7. Although constant values of the ohmic resistance of the solution $\left(3-4 \Omega \mathrm{cm}^{2}\right)$ were obtained, the Rs is a little smaller than that obtained for $42.2 \mathrm{k}$ steel corrosion in the same liquid concentrate. Plausible values of the capacity of the electrochemical double layer (CPE-T value of $11-125 \mu \mathrm{F} / \mathrm{cm}^{2}$ ) were calculated, which are usual for a metal/aqueous solution interface. The values of the CPE- $p$ exponent are in the range 0.92-1, which confirms that the $\mathrm{Al}$ alloy behaves almost as an ideal double-layer capacitor. In the final column, $R p$ polarization resistance decreases continuously with more anodic polarization, confirming the continuous process of $\mathrm{Al}$ alloy corrosion shown by polarization curves (Figure 9). It should be noted that imposing maximum anodic overpotential of $1 \mathrm{~V}$ from the stationary potential $($ at $+210 \mathrm{mV})$ led to an EIS spectrum that could not be modeled correctly by the proposed equivalent circuit. In said case, more complex circuits are needed as models-for example, with two parallel circuits connected in series with Rs. 

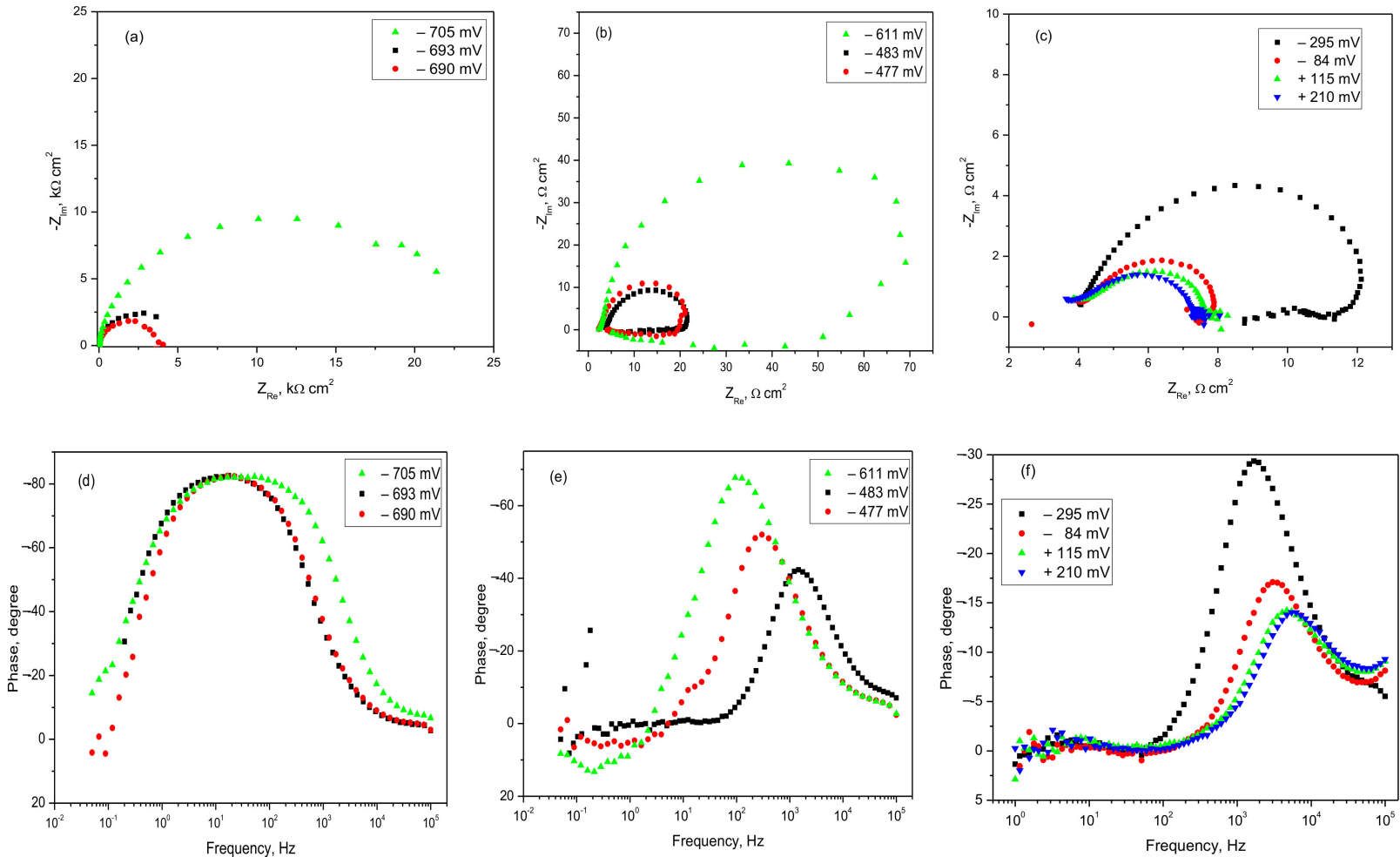

Figure 10. Nyquist spectra (a-c) and Bode phase angle spectra (d-f) for AlSiCuMg alloy in Profoam at various electrode potentials starting from $-705 \mathrm{mV}(\mathrm{OCP})$.

Table 7. Values of equivalent circuit parameters for corrosion of Al alloy in Profoam concentrate.

\begin{tabular}{ccccc}
\hline Anodic Polarization, $\mathbf{m V}$ & $R s, \Omega \mathrm{cm}^{2}$ & $C P E-T, \mu \mathrm{F} / \mathbf{c m}^{2}$ & $C P E-p$ & $R \boldsymbol{p}, \mathbf{\Omega} \mathbf{c m}^{2}$ \\
\hline-705 & 3.3 & 111.98 & 0.939 & 25352 \\
\hline-693 & 3.2 & 97.01 & 0.948 & 5933 \\
\hline-690 & 4.4 & 28.60 & 0.926 & 2831 \\
\hline-611 & 3.0 & 125.47 & 0.926 & 78 \\
\hline-483 & 4.1 & 10.95 & 1.010 & 17 \\
\hline-477 & 2.8 & 99.39 & 0.938 & 16 \\
\hline-295 & 4.2 & 13.58 & 1.018 & 7.4 \\
\hline-84 & 4.2 & 13.06 & 1.016 & 3.5 \\
\hline+115 & 4.2 & 24.50 & 0.920 & 3.2 \\
\hline
\end{tabular}

\section{Conclusions}

Weight-loss measurements of mild steel and aluminum alloy ( $\mathrm{AlSiCuMg}$ ) corroded in Fomtec P 6\% and 6\% P Profoam 806 protein-based foam concentrates showed that Al alloy experienced a lower weight-loss rate than the carbon steel.

However, the general tendency of both materials is to reach the largest corrosion rate in the first period of exposure, followed by a stationary state for prolonged immersion, during which almost constant corrosion rates were recorded.

SEM images exhibited the formation of layers containing corrosion products and localized corrosion occurrence. EDS elemental analyses showed a decrease in metal (iron, aluminum) content in the corrosion product layer (compared to about $99 \%$ in mild steel and $77 \%$ in $\mathrm{Al}$ alloy) and significant enrichment in oxygen, silicon, carbon, nitrogen and chlorine-i.e., non-metallic elements as components of the oxide/hydroxide compounds or salts. 
The corrosion rates calculated from corrosion current density using the potentiodynamic polarization are in good agreement with those obtained from weight-loss measurements, although they are an order of magnitude higher. No obvious passive region was recorded, except for some current oscillations within the anodic branch observed for both steel and $\mathrm{Al}$ alloy in Profoam, which confirms once again the greater aggressiveness of the Profoam than Fomtec. Impedance spectra showed each time a single capacitive semicircle on the Nyquist curve and a single maximum phase angle on the Bode diagram.

Calculated data for the best fitted elements of the simulated equivalent circuit revealed plausible values for solution resistance and capacity of the electrical double layer. Values of polarization resistance for steel corrosion had small fluctuations, which may have been due to the fact that iron as a steel alloying element can form some stable compounds in the presence of hydrolyzed proteins; clear passivation occurred only at high anodic polarization. Polarization resistance for $\mathrm{Al}$ corrosion decreased continuously with more anodic polarization, confirming the continuous process of corrosion.

Regarding the action of proteins existing in the foam concentrates, they can promote complexation of metal (iron, aluminum) cations in the electrolyte, and therefore, uniform corrosion is accelerated by their diminished concentration. All reported results can be used to improve safety in firefighting services.

Author Contributions: Conceptualization, T.V. and A.C. (Adina Cotarta); methodology, A.C. (Adina Cotarta) and C.B.; validation, A.C. (Adina Cotarta), T.V. and D.I.V.; formal analysis, M.T.P. and A.D.B.; investigation, M.T.P., A.D.B., C.B., A.C. (Adina Cotarta) and A.C. (Anca Cojocaru); resources, A.D.B.; writing - original draft preparation, A.C. (Anca Cojocaru); writing—review and editing, T.V. and D.I.V. All authors have read and agreed to the published version of the manuscript.

Funding: Authors acknowledge EU-funding grant POSCCE-A2-O2.2.1-2013-1, Priority Direction 2, Project No. 638/12.c03.2014, CodeSMIS-CSrNR 48652.

Institutional Review Board Statement: Not applicable.

Informed Consent Statement: Not applicable.

Data Availability Statement: The data presented in this paper are available on request from the corresponding author.

Conflicts of Interest: The authors declare no conflict of interest.

\section{References}

1. Foorginezhad, S.; Mohseni-Dargah, M.; Firoozirad, K.; Aryai, V.; Razmjou, A.; Abbassi, R.; Garaniya, V.; Beheshti, A.; Asadnia, M. Recent advances in sensing and assessment of corrosion in sewage pipelines. Process Saf. Environ. Prot. 2021, 147, 192-213. [CrossRef]

2. Bertschy, A.V.; Peterson, H.B. Corrosion Resistance of Some Common Metals to Concentrated and $6 \%$ Solutions of Light Water FireExtinguishing Agent; NRL Report 6932; Naval Research Laboratory: Washington, DC, USA, 1969.

3. Scheffey, J.L.; Wright, J.A. Analysis of Test Criteria for Specifying Foam Firefighting Agents for Aircraft Rescue and Firefighting. Appendix A.; Report DOT/ FAA/CT-94-04; FAA Technical Center: Atlantic City, NJ, USA, 1994.

4. Su, P.; Fuller, D.B. Corrosion and Corrosion Mitigation in Fire Protection Systems; Res Tech Report, 0003040794; FM Global: Johnston, RI, USA, 2014.

5. Radwan, K.; Rakowska, J.; Ślosorz, Z. Impact of surfactants used in extinguishing agent to corrosiveness of firefighting equipment, chapter 27. In Advances and Trends in Engineering Sciences and Technologies; Al Ali, M., Platko, P., Eds.; CRC Press/Balkema: London, UK, 2015; pp. 159-164.

6. Tihen, J. Corrosion in Fire Sprinkler Systems. Potter Signal Electric Co. 2014. Available online: https://www.abspk.org.br/CBSpk/ Apresentacoes/Dia05-15\%20-\%20Painel\%203\%20-\%20JOSH\%20TIHEN.pdf?pdf=PDF-05-15 (accessed on 4 August 2018).

7. Ryan Fireprotection Inc. The Solution for Corrosion in a Fire Sprinkler System. 2014. Available online: https://www.ryanfp.com/ solution-for-corrosion/ (accessed on 4 August 2018).

8. FM Global. Corrosion in automatic sprinkler systems. In FM Global Property Loss Prevention Data Sheets 2-1. 2016, pp. 1-19. Available online: https:/ / unitedfiresystems.net/wp-content/uploads/2018/11/01-Loss-Prevention-Data-Sheet-2-1-Corrosionin-Automatic-Sprinkler-Systems-FM-Global-Oct-20161.pdf (accessed on 4 August 2018).

9. Merwin, J. Corrosion in Fire Sprinkler Systems Increasing Your Liability, Increasing Your Costs, and Shortening System Life. Potter/Corrosion Solutions: 1-5. 2016. Available online: www.ifma-afc.org/docs/submissions/20160718_AFC_ PotterCorrosionSolutions.pdf (accessed on 4 August 2018). 
10. O'Connor, J. Inhibiting sprinkler pipe corrosion with nitrogen generation technology. Int. Fire Prot. 2017, 98-100.

11. Knurek, M. The Problem of Corrosion in Metal Fire Sprinkler Systems. Gulf Fire 5. 2017. Available online: https://gulffire. mdmpublishing.com/the-problem-of-corrosion-in-metal-fire-sprinkler-systems / (accessed on 4 August 2018).

12. Broadley, S. Corrosion in Fire Sprinkler Systems. Potter/Corrosion Solutions. 2017. Available online: https://www.fgsikring.no/ .../stephen-broadley---potter-electric-signal-company.pdf (accessed on 4 August 2018).

13. Hopkins, M. An Introduction to Corrosion in Sprinkler Systems: Its Identification and Mitigation; National Fire Sprinkler Association (NFSA): Anne Arundel, MD, USA, 2018; p. 2019.

14. Quick Response Fire Supply. \#223, Fire Sprinkler System Pipe Material: NFPA Requirements and the Pros and Cons of Steel; QRFS: Ashland, VA, USA, 2019.

15. Carpen, L.; Ohligschläger, T. A case study on corrosion of stainless steel in firewater mains. In Proceedings of the 6th European Stainless Steel Conference-Science and Market, Helsinki, Finland, 10-13 June 2008; pp. 129-135.

16. Carpen, L. Corrosion of Stainless Steel in Fire Protection Systems; Res Report VTT-R-01556-08; Technical Research Centre of Finland: Espoo, Finland, 2008.

17. Su, P.; Doerr, W.W. Fire protection sprinkler system for extremely corrosive industrial duct environments. Process Saf. Prog. 2010, 29, 70-2978. [CrossRef]

18. Su, P.; Tatar, F.W.; Chivukula, S.; Doerr, W.W. Weld Seam Corrosion of Steel Sprinkler Pipe; NACE Int Conf: Orlando, FL, USA, 2013; p. 2140.

19. Su, P.; Fuller, D.B. Steel piping material corrosion: Dry and pre-action fire protection systems. Sprink. Age 2013, 22-26.

20. Su, P.; Chivukula, S.; Tatar, F.W.; Swinnerton, B. Corrosion of Sprinkler Piping under Compressed Nitrogen and Air Supervision; NACE Int Conf: Dallas, TX, USA, 2015; p. 5548.

21. Laundess, A.J.; Rayson, M.S.; Dlugogorski, B.Z.; Kennedy, E.M. Small-scale test protocol for firefighting foams DEF(AUST)5706: Effect of bubble size distribution and expansion ratio. Fire Technol. 2011, 47, 149-162. [CrossRef]

22. Moe, M.K.; Huber, S.; Svenson, J.; Hagenaars, A.; Pabon, M.; Trümper, M.; Berger, U.; Knapen, D.; Herzke, D. The structure of the fire fighting foam surfactant Forafac ${ }^{\circledR} 1157$ and its biological and photolytic transformation products. Chemosphere 2012, 89, 869-875. [CrossRef] [PubMed]

23. Laundess, A.J.; Rayson, M.S.; Dlugogorski, B.Z.; Kennedy, E.M. Suppression performance comparison for aspirated, compressedair and in situ chemically generated class B foams. Fire Technol. 2012, 48, 625-640. [CrossRef]

24. Castro, J. Foam concentrates for the 21st century. Ind. Fire J. 2015, 36-41.

25. Wang, Q.; Shao, G.; Duan, Q.; Chen, M.; Li, Y.; Wu, K.; Liu, B.; Peng, P.; Sun, J. The efficiency of heptafluoropropane fire extinguishing agent on suppressing the lithium titanate battery fire. Fire Technol. 2016, 52, 387-396. [CrossRef]

26. Scheffey, J.L. Foam agents and AFFF system design considerations, chapter 47. In SFPE Handbook of Fire Protection Engineering, 5th ed.; Hurley, M., Ed.; Springer: Cham, Switzerland, 2016; pp. 1646-1706.

27. Korzeniowski, S.H.; Buck, R.C.; Kempisty, D.M.; Pabon, M. Fluorosurfactants in firefighting foams: Past and present, chapter 1. In Perfluoroalkyl Substances in the Environment: Theory, Practice and Innovation; Kempisty, D.M., Xing, Y., Racz, L.A., Eds.; CRC Press: Boca Raton, FL, USA, 2019.

28. Zaggia, A.; Conte, L.; Padoan, G.; Bertani, R. Synthesis and application of perfluoroalkyl quaternary ammonium salts in protein-based fire-fighting foam concentrates. J. Surfact. Deterg. 2010, 13, 33-40. [CrossRef]

29. Zhao, M.; Ni, X.; Zhang, S.; Cao, W.; Guan, Y.; Liang, C.; Wang, X.; Zhang, H. Improving the performance of fluoroprotein foam in extinguishing gasoline pool fires with addition of bromofluoropropene. Fire Mater. 2016, 40, 261-272. [CrossRef]

30. Kang, W.; Yan, L.; Ding, F.; Guo, X.; Xu, Z. Experimental study on fire-extinguishing efficiency of protein foam in diesel pool fire. Case Stud. Therm. Eng. 2019, 16, 100557. [CrossRef]

31. Hinnant, K.M.; Conroy, M.W.; Ananth, R. Influence of fuel on foam degradation for fluorinated and fluorine-free foams. Colloids Surf. A 2017, 522, 1-17. [CrossRef]

32. Hinnant, K.M.; Giles, S.L.; Ananth, R. Measuring fuel transport through fluorocarbon and fluorine-free firefighting foams. Fire Saf. J. 2017, 91, 653-661.

33. Hinnant, K.M.; Giles, S.L.; Snow, A.W.; Farley, J.P.; Fleming, J.W.; Ananth, R. An analytically defined fire-suppressing foam formulation for evaluation of fluorosurfactant replacement. J. Surfact. Deterg. 2018, 21, 711-722. [CrossRef]

34. Giles, S.L.; Snow, A.W.; Hinnant, K.M.; Ananth, R. Modulation of fluorocarbon surfactant diffusion with diethylene glycol butyl ether for improved foam characteristics and fire suppression. Colloids Surf. A 2019, 579, 123660. [CrossRef]

35. Ananth, R.; Snow, A.W.; Hinnant, K.M.; Giles, S.L.; Farley, J.P. Synergisms between siloxane-polyoxyethylene and alkyl polyglycoside surfactants in foam stability and pool fire extinction. Colloids Surf. A 2019, 579, 123686. [CrossRef]

36. Hinnant, K.M.; Giles, S.L.; Smith, E.P.; Snow, A.W.; Ananth, R. Characterizing the role of fluorocarbon and hydrocarbon surfactants in firefighting-foam formulations for fire-suppression. Fire Technol. 2020, 56, 1413-1441. [CrossRef]

37. Schaefer, T.H.; Dlugogorski, B.Z.; Kennedy, E.M. Sealability properties of fluorine-free fire-fighting foams (FfreeF). Fire Technol. 2008, 44, 297-309. [CrossRef]

38. Wang, P. Application of green surfactants developing environment friendly foam extinguishing agent. Fire Technol. 2014, 51, 503-511. [CrossRef]

39. Sheng, Y.; Jiang, N.; Sun, X.; Lu, S.; Li, C. Experimental study on effect of foam stabilizers on aqueous film-forming foam. Fire Technol. 2018, 54, 211-228. [CrossRef] 
40. Sheng, Y.; Jiang, N.; Lu, S.; Wang, Q.; Zhao, Y.; Liu, X. Study of environmental-friendly firefighting foam based on the mixture of hydrocarbon and silicone surfactants. Fire Technol. 2020, 56, 1059-1075. [CrossRef]

41. Wood Comp; Ramboll Comp; COWI Group. The Use of PFAS and Fluorine-Free Alternatives in Fire-Fighting FoamsFinal Report; Report for the European Commission DG Environment and European Chemicals Agency. 2020. Available online: https:/ / echa.europa.eu/documents/10162/28801697/pfas_flourine-free_alternatives_fire_fighting_en.pdf/d5b24e2a-d0 27-0168-cdd8-f723c675fa98 (accessed on 1 September 2018).

42. Solberg Company Bergen, Norway Re-Healing Foam; Technical Reference Guide, Section 2. In Foam Systems Design and Application Manual. 2017, p. 11. Available online: https://ufppro.com/wp-content/uploads/2018/03/Kopiya-SOLBERGDesign-Application-Manual-F-2013014-6_EN-1.pdf (accessed on 1 September 2018).

43. Tyco Fire Protection Products, Lansdale, PA, US, Acceptable Materials of Construction for Use with Firefighting Foam Concentrates. Techn. Bull. T-2016111. 2016. Available online: https://www.williamsfire.com/uploads/media/T-2016111_-_Acceptable_ Materials_of_Construction.pdf (accessed on 1 September 2018).

44. Safyari, M.; Hojo, T.; Moshtaghi, M. Effect of environmental relative humidity on hydrogen-induced mechanical degradation in an Al-Zn-Mg-Cu alloy. Vacuum 2021, 192, 110489. [CrossRef]

45. Moshtaghi, M.; Safyari, M.; Kuramoto, S.; Hojo, T. Unraveling the effect of dislocations and deformation-induced boundaries on environmental hydrogen embrittlement behavior of a cold-rolled Al-Zn-Mg-Cu alloy. Int. J. Hydrog. Energy 2021, 46, 8285-8299. [CrossRef]

46. Peterson, H.B.; Burnett, J.C. The Corrosive Effects of Protein-Type Foam-Forming Concentrates on Common Metals and Dissimilar Metal Couples; NRL Report 4947; Naval Research Laboratory: Washington, DC, USA, 1957.

47. Rakowska, J.; Ślosorz, Z. Corrosion of fire estinguishing systems and firefighting fittings. Saf. Fire Tech. 2011, $24,113-120$.

48. Radwan, K.; Rakowska, J.; Slosorz, Z. Corrosion of fire fighting equipment caused by surfactants used in extinguishing agent. In Proceedings of the International Conference in Engineering Sciences and Technologies (ESaT 2015), Tatranska Strba, High Tatras Mountains, Slovakia, 27-29 May 2015.

49. Kostyaev, A.A.; Balmasov, A.V.; Inasaridze, L.N. Effect of inhibitors on carbon steel corrosion in foaming solutions. Russ. J. Gen. Chem. 2016, 86, 429-433. [CrossRef]

50. Elahresh, N.; Jewilli, F. Evaluation of fire extinguishing foam concentrate for 304 stainless steel. In Proceedings of the 4th International Technology of Oil and Gas, TOG 2008, Tripoli, Libya, 21-23 October 2008; p. TOG-78.

51. De la Fuente, D.; Díaz, I.; Alcantara, J.; Chico, B.; Simancas, J.; Llorente, I.; García-Delgado, A.; Jimenez, J.A.; Adeva, P.; Morcillo, M. Corrosion mechanisms of mild steel in chloride-rich atmospheres. Mater. Corros. 2016, 67, 227-238. [CrossRef]

52. Huang, W.H.; Yen, H.W.; Lee, Y.L. Corrosion behavior and surface analysis of 690 Mpa-grade offshore steels in chloride media. J. Mater. Res. Technol. 2019, 8, 1476-1485. [CrossRef]

53. Xiao, H.; Ye, W.; Song, X.; Ma, Y.; Li, Y. Evolution of akaganeite in rust layers formed on steel submitted to wet/dry cyclic tests. Materials 2017, 10, 1262. [CrossRef]

54. Kocijan, A.; Milosev, I.; Pihlar, B. The influence of complexing agent and proteins on the corrosion of stainless steels and their metal components. J. Mater. Sci. Mater. Med. 2003, 14, 69-77. [CrossRef] [PubMed]

55. Rojas, C.R.; Lago, M.E. Effects of proteins in corrosion of stainless steel used in traumatology. Corros. Rev. 2005, 23, 445-459. [CrossRef]

56. Geringer, J.; Pellier, J.; Taylor, M.L.; Macdonald, D.D. Fretting corrosion with proteins: The role of organic coating on the synergistic mechanisms. Thin Solid Films 2013, 528, 123-129. [CrossRef]

57. Hedberg, Y.S. Role of proteins in the degradation of relatively inert alloys in the human body. Mater. Degrad. 2018, 2, 26-31. [CrossRef]

58. Atapour, M.; Wallinder, I.O.; Hedberg, Y. Stainless steel in simulated milk and whey protein solutions-Influence of grade on corrosion and metal release. Electrochim. Acta 2020, 331, 135428. [CrossRef]

59. Wagener, V.; Faltz, A.-S.; Killian, M.S.; Schmuki, P.; Virtanen, S. Protein interactions with corroding metal surfaces: Comparison of Mg and Fe. Faraday Discuss. 2015, 180, 347-360. [CrossRef] [PubMed]

60. Salem, Y.; Oudbashi, O.; Eid, D. Characterization of the microstructural features and the rust layers of an archaeological iron sword in the Egyptian Museum in Cairo (380-500 A.D.). Heritage Sci. 2019, 7, 19. [CrossRef]

61. Mobin, M.; Aslam, R. Experimental and theoretical study on corrosion inhibition performance of environmentally benign non-ionic surfactants for mild steel in 3.5\% NaCl solution. Process Saf. Environ. Prot. 2018, 114, 279-295. [CrossRef]

62. Rabizadeh, T.; Asl, S.K. Casein as a natural protein to inhibit the corrosion of mild steel in $\mathrm{HCl}$ solution. J. Mol. Liq. 2019, 276, 694-704. [CrossRef]

63. Hendy, A.; El-Nady, J.; Hassan, N.; Tamer, T.M.; Ahmed, A.S.I.; Abou Shahba, R.M. Corrosion inhibition of casein as a natural protein for 316L stainless steel in simulated body fluid. Al-Azhar Bull. Sci. 2020, 31, 11-18. [CrossRef]

64. Clark, G.C.F.; Williams, D.F. The effects of proteins on metallic corrosion. J. Biomed. Mater. Res. A 1982, 16, 125-134. [CrossRef] [PubMed]

65. Mueller, H.J. Effects of proteins on metal corrosion. In Proceeding of the International Metallographic Society Technical MeetingIMS Technical Meeting, ASM International, Ottawa, ON, Canada, 1-4 November 1999.

66. Boag, A.; Hughes, A.E.; Glenn, A.M.; Muster, T.H.; McCulloch, D. Corrosion of AA2024-T3 Part I: Localised corrosion of isolated IM particles. Corros. Sci. 2011, 53, 17-26. [CrossRef] 